\title{
Mehmet Asaf'ın [Borsacı] Beyimin Edebiyata Merakı adlı tiyatro eseri ve incelemesi
}

\author{
Selami ALAN 1
}

\begin{abstract}
APA: Alan, S. (2020). Mehmet Asaf'ın [Borsacı] Beyimin Edebiyata Merakı adlı tiyatro eseri ve incelemesi. RumeliDE Dil ve Edebiyat Araştırmalar Dergisi, (18), 140-169. DOI: 10.29000/rumelide.705565.
\end{abstract}

\section{Öz}

Mehmet Asaf [Borsacı] tarafindan yazılan ve 1918 yılında yayınlanan Beyimin Edebiyata Merakı adlı tiyatro oyunu bir perde ve beş meclisten oluşmaktadır. Komedi türünde kaleme alınan bu oyunda, dönemin güncel edebî konuları ele alınır. Bu konular arasında öne çıkanlar; hece-aruz, eski-yeni, şiir dili, muhteva ve millî-gayrı millî tartışmalarıdır. Mehmet Asaf, bu konuları anlatabilmek için oyunda karşıt iki grup oluşturur. Bu gruplara savundukları vezinle şiirler okutur. Böylece hece ile aruz vezinlerinin kıyaslanabilmesi için ortam oluşturur. Muallim Naci, Mehmet Celal, Cenap Şahabettin, Süleyman Nazif, Recaizade Mahmut Ekrem gibi dönemin önde gelen edebiyatçllarından bahsederek şiirde eskilik-yenilik konusuna değinir. Nitekim oyunun ilerleyen kısımlarında millî edebiyatın sınırlarını sorgular ve yüzyıllardır yazılan edebî eserlerin millî kabul edilip edilmeyeceğini sorar. Mehmet Asaf edebî tartışmalar üzerine bina ettiği bu oyunu; anne, baba, oğul, hizmetçiler ve bir misafirden ibaret bir aile ortamında işler. Mekân olarak da bir konak odasını kullanır. Oyundaki kahramanları dönemin yaşayan, günlük diliyle konuşturur. Fakat tartışmalarda geçen örneklerde Arapça, Farsça kelime ve tamlamalara da yer verir. Oyunda kesin bir zaman belirtmez. Fakat eserin muhtevasından hareketle olayların II. Meşrutiyet sonrası ile oyunun basım tarihi olan 1918 arasında bir zaman diliminde gerçekleştiği söylenebilir. Netice itibariyle, Beyimin Edebiyata Merakı adlı tiyatro eseri üzerine yapılan bu makalenin amacı, hem eseri günümüz alfabesine aktararak güncel edebiyata kazandırmak hem de daha çok gazeteciliği ile bilinen Mehmet Asaf’ın edebî kişiliğine dikkat çekmektir.

Anahtar kelimeler: Mehmet Asaf [Borsacı], hece-aruz tartışması, millî edebiyat, millî-gayrı millî tartışması.

\section{Mehmet Asaf's (Borsacı) Beyimin Edebiyata Merakn theatre work and review}

\begin{abstract}
Written by Mehmet Asaf [Borsacı] and published in 1918, theatre of Beyimin Edebiyata Merakı consists of one stage and five chambers. In this play, written in the genre of comedy, the current literary style of the period is discussed. Among these topics, the highlights are syllabic/aruz, old/new, poetry language, content and national/non-national discussions. Mehmet Asaf forms two opposing groups to explain these issues. He makes these groups say poems to the extent they defend. Thus, it creates an environment for comparing syllabic and aruz poet. meters. He mentions the leading writers of the period such as Muallim Naci, Mehmet Celal, Cenap Şahabettin, Süleyman Nazif, Recaizade Mahmut Ekrem and mentions the subject of old-new in poetry. As a matter of fact, he questions the boundaries of national literature and asks whether the literary works written for
\end{abstract}

Öğr. Gör. Dr., Bolu Abant İzzet Baysal Üniversitesi, Türk Dili Bölümü (Bolu, Türkiye), selami.alan@ibu.edu.tr, ORCID ID: 0000-0001-7388-0430 [Makale kayit tarihi: 06.01.2020-kabul tarihi: 20.03.2020; DOI: 10.29000/rumelide.705565] 
centuries will be accepted as national. Mehmet Asaf uses this text in a family environment consisting of mother, father, son, servants and a guest. The scene used in the text is a mansion room. He makes the heroes speak the living, everyday language of the era. However, Arabic, Persian words and phrases are included in the examples in the discussions. He does not specify an exact time in the theater. However, looking at the content of the work, it can be said that the events took place between the Constitutional Monarchy and 1918. The aim of this article, which is based on theatrical work named Beyimin Edebiyata Merakı, is to bring the work into contemporary literature by transferring it to the present alphabet and to draw attention to the literary personality of Mehmet Asaf, who is mostly known for his journalism.

Keywords: Mehmet Asaf [Borsacı], syllable-aruz discussion, national literature, national-nonnational discussion.

\section{Giriş}

Toplumların yaşadıkları siyasî, sosyal ve kültürel değişim ve gelişmelerin göstergelerinden biri, o yıllarda kaleme alınan edebî metinlerdir. Zira bazen yeniliğin öncülüğünü bazen de mevcudun muhafızlı̆̆ını yapan fikir ve sanat insanları, o günlerde yaşananları yansıtmanın yanı sıra edebî eserler vasıtasıyla kendi düşüncelerini halka aktararak kamuoyu oluşturmaya çalışmışlardır. Bu sanatçı ve eserlerden bazıları başarılı ve popüler olup edebiyat tarihinde yerini almış, bazıları ise farklı sebeplerle arka planda kalarak zaman içinde unutulmuştur. Halbuki bunların hatırlanması ve güncele aktarılması Türk edebiyatına katkı sağlayacaktır. Bu bakış açısıyla yapılan bu çalışmada, Türk edebiyat tarihi içerisinde unutulan isim ve eserler arasında yer alan Mehmet Asaf [Borsacı] ve tiyatro eseri Beyimin Edebiyata Merakı ele alınmıştır.

Türk kültür tarihinde daha çok gazeteciliğiyle tanınan Mehmet Asaf, 20 Ekim 1874 tarihinde İstanbul'da dünyaya gelmiştir. Aslen Bolulu olan Kurmay Binbaşı Hüseyin Hüsnü Bey ile Nadire Rukiye Hanım’ın çocuklarıdır. Annesi, dönemin etkili ismi Namık Kemal'den edebiyat dersleri alarak hürriyet fikri ve politikayla ilgilenmiş bir kadındır. Baba tarafından Hafız İbrahim Efendi'nin, anne tarafından da "Kâğıtçı Başı" diye tanınan Arapkirli Hacı Halil Ağa’nın torunudur. Mehmet Asaf’ın dayısı Tahsin Efendi ise hem Namık Kemal ve İbrahim Şinasi gibi edebiyatçılarla dost olan hem de II. Abdülhamit dönemi İstanbul'unda siyasî nitelikli Sadakat gazetesini gündelik olarak çıkaran çok yönlü biridir. Böyle edebî ve siyasî yönelimleri olan aydın bir aile ortamında yetișen Mehmet Asaf, aynı zamanda Numune-i Terakki Mektebi, Beyazıt Rüştiyesi ve bir müddet de Vefa İdadisi’nde öğrenim görmüştür. İyi bir eğitim alan yazarın, Türk edebiyat dünyasına ilk katkısı ise 15 Mayıs 1900 tarihinde Terakki dergisinde yayımlanan "Âlem-i Mehtap" isimli mensur bir şiirle gerçekleşmiştir (Çapanoğlu 1961: 27-28). Daha sonraki yllarda Tarik, Sabah, İkdam, Malumat, İrtika, Musavver Fen ve Edep, Gayret, Serbesti, Cingöz, Gıdık, Zümrüt-ü Anka, Ayna, Kadınlar Dünyası, Hanımlar Âlemi ve Boş Boğaz gibi birçok gazete ve dergide yazarlık ve başyazarlık yapmış, idari görevler üstlenmiştir (İnuğur 1993: 162-167). Bu gazete ve dergilerde kaleme aldığı özellikle mizahî yazılarda ise Muhasib-i Şu'un, Sansar, Sinek, Neşide Asaf, Konsolitçi ve Turhan Deli takma isimlerini kullanmıştır (Iş̧ı 2007: 731).

Türk siyasî ve sosyal tarihinin II. Abdülhamit, İttihat ve Terakki, Mütareke yılları, Millî Mücadele ve Cumhuriyet'in ilanı gibi değişik dönemlerine tanıklık eden Mehmet Asaf, yeri geldiğinde mevcut hükümetlerin icraatlarını eleştirmekten çekinmeyen yazılar kaleme almıştır. Bazı yazıları dolasıyla takdir gördüğü gibi bazılarındaki mizahî ve iğneleyici üslup sebebiyle de zaman zaman ceza çekmekten kurtulamamıştır. Aslında mizahi yazılarında Ahmet Rasim’i örnek almış ve yazılarında kaba ve küfürlü 
ifadelere yer vermemiş; yanlışları ve sosyal gerçekleri gülümseterek vermeye çalışmıştır (Çapanoğlu 1961: 19). Tenkitlerinde şahısları değil yapılan yanlış işleri hedef almıştır (Çapanoğlu 1961: 6). Buna rağmen hakkındaki suçlamalar nedeniyle bazen bir dostunun evinde günlerce saklanmak zorunda kalmış bazen tutuklanıp mahkeme edilmiş bazen de aldığı sürgün cezası dolayısıyla İstanbul'dan aylarca uzak kalmıştır. Hatta onu öldürmek niyetindeki bir fedai tarafından takip edildiği olmuştur. Böyle dönemlerde Abdülhak Şinasi'nin annesi Neyyir Hanımefendi ve Ömer Seyfettin gibi dostlarından değişik yardımlar gören Mehmet Asaf, gözleri artık yaşlılıktan dolayı görmez olana kadar yazmaya devam etmiştir.

Mehmet Asaf, neredeyse ömür boyu süren gazeteciliğin yanında şiir, roman, tiyatro gibi değişik türde birçok eser kaleme almış ve bunlardan otuz kadarı basılmıştır (Çapanoğlu 1961: 6). Yazarın bu eserlerinden bazıları şunlardır: Dilârâ (1902), Mihriban (1914), Zavall Baba (1914?), Beyimin Edebiyata Merakn (1918), Sinirli Bey (1918), Yeni Hantm Mektuplarn (1920), Benli Leyla (1922), Cilveli Rânâ (1925), Findıkçı Nigâr (1925), İkisi De Gebe (1925), Kuşdili Gelini (1925), Şivekâr Hanım (1925), Kaymaca Kulübü (1927), Lamia'nın Sergüzeşti (1927), Üçü Bir Yatakta (1927), Kocamın Kocası (1929), Sinirli Hanım, Bihterle Muhlis, Şadiye, Küçük Hanımın Kedileri, Bekâr Kızlara Mektuplar, Abanoz Kizının Defteri. ${ }^{2}$

Şiirlerinde Muallim Naci'nin etkisinde kalan Mehmet Asaf, özgün bir tarz oluşturamamıştır. Eski ile yeni arasında manzume niteliğinde şiirler yazmıştır. Daha ziyade divan edebiyatına yaklaşan üslubuyla bazı güzel mısra ve beyitlerin haricinde Türk şiirine orijinal bir katkıda bulunamamıştır. Sonraki dönemlerde Rıza Tevfik'in izinde âşık tarzı şiir ve nefesler yazarak bunlardan bazılarını kendi dergisinde yayımlamıştır (Çapanoğlu 1961: 10). Teknik açıdan hikâye olarak nitelendirilebilecek romanlarında ise daha çok acıklı sonla biten gönül maceralarını ele almıştır. Mehmet Asaf, bu eserlerine her ne kadar modern roman özelliği kazandıramasa da dönemin İstanbul'unda yaşayan tipik ve karakteristik insanları gerçekçi bir şekilde yansıtmayı başarmıştır (Çapanoğlu 1961: 12). Dolayısıyla yazarın bu türlerde yayımladığı eserlerin ancak birer deneme boyutunda kaldığı söylenebilir. Yazarın tiyatro türündeki durumunu ise araştırmada incelenen Beyimin Edebiyata Merakı adlı eseri üzerinden değerlendirmek mümkündür.

\section{“Gülünçlü Bir Komedi”: Beyimin Edebiyata Merak»3}

İstanbul'da Cemiyet Kütüphanesi tarafından Rumi 1334 / Miladi 1918 yllında Necm-i İstikbâl Matbaası'nda (Matbaa-i Orhaniye) bastırılan Beyimin Edebiyata Merakı adlı tiyatro oyunu bir perde ve beş meclisten oluşmaktadır.

\section{Eserin muhtevası}

Mehmet Asaf, komedi türünde kaleme aldığı Beyimin Edebiyata Merakı adlı tiyatrosunda, dönemin popüler edebiyat akımı olan Millî Edebiyat anlayışına karşı çıkar. "Dildeki millileşmeyi TürkçülükTurancılık hareketinin tesiriyle aşırıya götürenler"i alaycı bir dille eleştirir ve "eski edebiyatın da bize ait olduğunu, onu tamamiyle atmamızın mümkün olmadığı”nı (Töre 2008: 224) ifade eder. Bu oyun hakkında kısa bir değerlendirmede bulunan Metin And ise yazarın eski ve yeni şiir anlayışlarını konu edinmesini kuşaklar arasındaki değer ve görüş farklılıklarını yansıtma düşüncesine bağlar. Mehmet Asaf’n, altmış sekiz yaşındaki Hayrettin Efendi ile on sekiz yaşındaki Mehmet Bey arasındaki görüş

Yazarın eserleriyle ilgili kaynaklar: (Çapanoğlu 1961: 12); Seyfettin Özege Koleksiyonu. Mehmet Asaf (1334/1918). Beyimin Edebiyata Merakı, İstanbul: Necm-i İstikbâl Matbaası. 
ayrılığını "çağın edebiyat eğilimleri açısından" (And 1971: 166) ortaya koyduğunu belirtir. Fakat yazarın bu eserdeki temel gayesinin kuşaklar arasında yaşanan çatışmayı sergilemekten ziyade Millî Edebiyat fikrine karşı klasik edebiyat anlayışını savunmak olduğu söylenebilir. Çünkü eski edebiyat değerlerine bağlllık yönüyle Hayrettin Efendi'nin yanı sıra, eserin başında otuz iki yaşında olduğunu belirttiği Ali Şadan Bey'e de yer verir. Ali Şadan Bey'i de eserde eğitimli, zeki ve uyanık bir genç olarak tanıtır. Böylece klasik şiir kültürünün aslında bilgili ve bilinçli gençler tarafından hâlâ kabul gördüğünü ve devam ettirildiğini göstermek ister. Öte yandan hece vezniyle şiirler yazmaya çalışan Mehmet Bey ve aşçıbaşı ile onlardan etkilenen Mesut'un on sekiz - yirmi bir yaş aralığında gençler olarak kurgular. Bu kurgu ise yazarın, Millı̂ Edebiyat akımını geçici bir gençlik hevesi gibi gördüğüne yönelik ilk işarettir. Bu bağlamda Mehmet Asafın eserdeki kahramanların yaşlarından bahsederken bir kuşak çatışmasını dile getirmekten ziyade; klasik şiir taraftarları ile yeni şiir taraftarlarını bilgi, birikim, ağırbaşlılık, geçici heves ve heyecan gibi değişik yönlerden kıyaslama düşüncesiyle hareket ettiği söylenebilir.

Mehmet Asaf eserinde, 19. yüzyıl sonları ile 20. yüzylın başlarında etkisini hissettiren hece-aruz meselesi, muhteva, şiirde eskilik-yenilik, şiir dilinin sadeleşmesi ve edebiyatta millîlik gibi konuları ele alır. Tiyatroda yer verilen bu konular arasında dikkat çekenlerden ilki, hece-aruz tartışmasıdır. Aslında Türk edebiyat tarihinde edebiyatçı/aydınlar arasında, yıllardan beri süregelen Doğu-Batı ve eski-yeni tarzında birçok tartışma mevcuttur. Daha çok kültür ve dil çerçevesinde gelişen bu tartışmalar, 1897 Türk-Yunan Savaşı sonrasında Mehmet Emin'in [Yurdakul] sade Türkçe ve hece vezniyle kaleme adlı şiirlerle farklı bir boyut kazanır. Mehmet Emin [Yurdakul], şiirlerini kitaplaştırmadan önce dönemin önde gelen şair ve yazarlarının görüşlerini almak ister. Onun bu talebi karşılığında görüş beyan edenlerden biri Rıza Tevfik olur. Rıza Tevfik, gönderdiği mektupta Türk halkının kullandığı millî Türkçeyi kullandığı için Mehmet Emin’i [Yurdakul] tebrik ederken kozmopolit bir Osmanlı Türkçesi kullandıklarını belirterek Servet-i Fünûncuları millî olmamakla ve yabancılıkla itham eder. Bu ithamlara karşı çıkan kişi ise Çocuk Bahçesi’nde yayımladığı "Evzan-ı Şi’riyyemize Dair” makalesiyle Ömer Naci olur. Servet-i Fünûn şiirini savunan Naci hem Mehmet Emin'in [Yurdakul] şiirlerini hem de onu beğenen ve savunan Rıza Tevfik'i eleştirir. Aruzun duygu ve düşünceleri anlatmada aktarım gücü, uygunluk, ses ve müzikalite gibi bakımlardan hece veznine nispetle daha güçlü olduğunu iddia eder (Çetin 2006: 604).

Muallim Naci'nin vezin hususunda savunduğu bu yaklaşım, Mehmet Asaf'ın Beyimin Edebiyata Merakı oyununa da olduğu gibi yansır. Oyundaki kahramanlardan Hayrettin Efendi'yi merhum Muallim Naci'nin samimi bir arkadaşı olarak kurgulayan Mehmet Asaf, Naci'nin fikirlerini onunla yaşatır. Örneğin oyunda Hayrettin Efendi, aşçıaşının heceyle yazdığı şiiri küçümser. Fakat okunan şiirin bir mısrasının aruz veznine uyduğunu anlayınca bu mısrayı tekrar okutturur ve "Ahenginden anlarım. Ne raksan vezindir, nerede olsa kendi gösterir.” (Mehmet Asaf 1334/1918: 33) diyerek aruz veznini över. Yine Hayrettin Efendi, Ali Şadan Bey'le sohbet ederken; "Bugünün şiirinde sorarım size bir zevk buluyor musunuz? Ne vezin var, ne kafiye...” (Mehmet Asaf 1334/1918: 17) sözleriyle, aruz vezni kullanılmadan yazılan şiirleri estetik bulmadığını ifade eder. Hayrettin Efendi’nin şiir hakkındaki bu düşünceleri, "hece veznine itibar etmiyerek bir Türk aruzu meydana getirmeye çalışmış” (Tarakçı 1994: 33) olan Muallim Naci'nin şiir anlayışıyla benzerlik gösterir.

Mehmet Asaf’n şiir anlayışında Muallim Naci ile benzerlik gösterdiği konulardan biri de şiirde dış güzelliğin yanı sıra muhteva da aramasıdır. "Mânâ bozuk olunca kafiyenin düzgün olması ne işe yarar?" (Tarakçı 1994: 24) diyen Muallim Naci gibi, şiirde anlam bütünlüğü olmasını ister ve her şeyin şiirin konusu olamayacağını söyler. Bu düşüncesini, aş̧̧ıbaşının "mercimek, nohut, bulgur çorbası, pirinç torbası, sakanın kırbası” gibi varlıklarla oluşturduğu şiire, yine Hayrettin Efendi’nin gösterdiği tepkiyle 
ortaya koyar. Oyunda yazarın fikirlerinin tercümanlığını yapan Hayrettin Efendi, aşçıbaşının yazıp okuduğu bu şiire; “"Haykırarak» Olmaz... Vallahi olmaz efendim... Bu ne maskaralık, bu ne rezalet... Sakanın kırbasına pirinç torbası kafiye olur mu? Hem efendim bulgur çorbasıyla nohudun şiirde ne yeri var?” (Mehmet Asaf 1334/1918: 30) diye karşı çıkar. Aslında bu şiirde vezin, kafiye ve redif gibi biçim unsurları mevcuttur. Fakat eski anlayışı savunan Hayrettin Efendi'ye göre herkes şair olamayacağı gibi sıradan ve basit mevzular da şiirin konusu olamaz. Çünkü onun gözünde, "edebiyat bir başka fen, bir başka ilim”dir (Mehmet Asaf 1334/1918: 20). Bu yüzden, oğlu Mehmet Bey ve aşçıbaşı gibi dönem gençlerinin basit kelimeler kullanarak sıradan olay ve eşyaları şiire konu etmelerinden rahatsız olur. Özellikle de gençlerin bu şiirleri, "Millî Edebiyat” ürünü olarak görmelerini kabul edemez.

Eserin temel meselelerinden bir diğeri, "Millî Edebiyat” konusudur. Zira Ali Canip [Yöntem], 1910 yılında Genç Kalemler dergisinde yayımlanan "Âtî-i Edebîmiz” başlıklı makalesinde, millî bir edebiyatın yokluğundan yakınır. Aynı yazıda; "Evet, Osmanlı gençleri bir 'edebiyyât-ı milliye' istiyorlar." (ParlatırÇetin 1999: 27) diyerek geleceğin hâkimi olarak gördüğü Osmanlı gençlerinin artık millı̂ bir edebiyat arzuladıklarını ve bu yolda eserler kaleme aldıklarını beyan eder. Böylece Türk edebiyatında ilk defa "Millî Edebiyat" tabirini de kullanmış olur (Dayanç 2012: 92)4. Ali Canip’in millî bir edebiyat isteği aslında Tanzimat sonrasında yaşanan değişimin neticelerinden biridir. Çünkü edebiyatçı/aydınlar, yeni hayat şartlarına ayak uyduracak yeni insanlar hayal etmekte ve edebiyatı, bu hayale ulaştıracak bir vasıta olarak görmektedirler. Mesela Namık Kemal, 1866 yılında Tasvir-i Efkâr'da yayımladığı "Lisân-ı Osmanînin Edebiyatı Hakkında Bazı Mülâhazatı Şamildir” makalesinde, toplumdan uzaklaşan klasik edebiyat yerine hem milleti anlatan hem de millete hitap eden yeni bir edebiyatın geliştirilmesi gerektiğini belirtir. Yeni çağda oluşturulacak bu yeni edebiyatın ise gerek yeni insanın ihtiyaçlarının karşılanmasında gerekse toplumun biçimlendirilmesinde etkin rol oynamasını ister. "Edebiyatın milli hayatı aksettirmesi gerektiğinin ifade edilmesiyle, bir anlamda 'Milli Edebiyat'ın ilk habercisi” (Yetiş 1999: 267) sayılabilecek bu yazıdaki fikirler; Şemsettin Sami, Ali Suavi, Necip Asım, Ahmet Vefik Paşa, Süleyman Paşa, Mehmet Emin, Ömer Seyfettin ve Ziya Gökalp gibi birçok edebiyatçı/aydın tarafından değişik boyutlarıyla uzun yıllar tartışılır. Neticede Türk edebiyatında, dönemin etkin fikir akımı olan Türkçülüğün de etkisiyle "dilde sadeleşme (millî dil), vezinde heceyi tercih etme (millî vezin), tema olarak da başta Anadolu insanı olmak üzere toplumun alt katmanlarının sorunlarını dile getirme (millî konular) temel anlayışları üzerine bina edilen” (Dayanç 2012: 98) bir anlayış hâkim olur. Bu görüşü Ziya Gökalp, "Millı̂ Edebiyatın asıl poetikası" (Yetiş, 1999: 276) olarak kabul edilebilecek “Sanat” şiiriyle şöyle özetler:
"Aruz sizin olsun, hece bizimdir.
Halkın söylediği Türkçe bizimdir,
Leyl sizin, şeb sizin, gece bizimdir,
Değildir bir mana üç ada muhtaç."

Bu dörtlükte de görüldüğü üzere genelde dil, vezin ve konu çerçevesinde değerlendirilen millîlik kavramı, Türk edebiyatında uzun süre devam eden ve edecek yeni bir tartışmanın doğmasına sebep olur: Daha önceki edebiyatçılar ve onların kaleme aldıkları eserler gayr-ı millî midir?5 Yüzyıllardır Türk

Türk edebiyatında "millı̀” kelimesinin ve anlayışının ilk kullanımı aslında Tanzimat Edebiyatı Dönemi’nde gerçekleşir. Fakat bu devirde kelimeye yüklenen anlam, kelimenin II. Meşrutiyet Dönemi’nden itibaren taşıdığı "milliyetçi” anlamdan farklıdır. Tanzimat Edebiyatı Dönemi’nde ilk telif roman ve hikâyelerin üzerine yazılan "millı”" ibaresi; "tercüme olmayan, telif, yerli olan" manalarını taşımaktadır. Yine bu kullanış tarzı, Servet-i Fünûn devrinde de devam etmiştir (Ercilasun 1997: 457-458).

$5 \quad$ Edebiyatın millîliği meselesi Türk edebiyat tarihinde dönem dönem gündeme gelmiş ve Hüseyin Cahit'in ifadesiyle “arada sırada tazelenen müebbet mesele" (Özalp 2000: 26) olarak canlılığını korumuştur. 
edebiyatına eserler kazandıran sanatçılar; şiirlerini aruzla yazdıkları, Arapça/Farsça kelime ve tamlamalar kullandıkları ve toplumdan uzak konuları işledikleri için gayr-ı millı̂ mi sayılacaktır? Mehmet Asaf da tiyatrosunda, Hayrettin Efendi ile Şadan Bey aracılığıyla, konuya bu açıdan yaklaşır ve metinde benzer nitelikte sorulara yer verir. Şadan Bey, yazdıkları şiirlerle Millî Edebiyatı geliştirdiklerini iddia eden Mehmet Bey'e: "Bugüne kadar yazılmış olan şiirler ve nesirler, velhasıl bütün mahsulat-ı edebiyye; bizim malımız, bizim tercüman-ı his ve efkârımız değil de başkasının malı, başkasının tercüman-ı his ve efkârı mıdır?” (Mehmet Asaf 1334/1918: 21) diye sorar. Sonrasında ise şu cümlelerle millîliğin sınırlarını sorgular:

\begin{abstract}
“Evet efendim...Cenap’ın, Süleyman Nazifin, Faik Ali’nin asarı Millî Edebiyatın haricinde midir? Hem efendim rica ederim, edebiyatın, millîsi, ecnebisi ne oluyor? Aruz vezniyle ifade edilen hissiyat ve efkâr Boğaz’n mavi suları üstünde uçan kotraları, Ada'da bir levha-i gurubu, Rumeli Hisarı'nda bir şeb-i mehtâbı musavver olan bedayi-i edebiyye niçin ecnebi addediliyor da sonra Bolu Sancağının Mengen Kazasındaki bilmem ne köyünde pınardan testisini doldururken yamaçta kaval çalan çobana bir nigâh-ı iştiyâk firlatan köylü kızını musavver olan sözler ve yazılar millî sayılıyor?” (Mehmet Asaf 1334/1918: 21).
\end{abstract}

Eserde yazarın sözcüsü olan Hayrettin Efendi; bir şiirin millî sayllabilmesi için hece vezniyle yazılıp kavaldan, çobandan, pınardan, köyden ve köylüden bahsetmesinin yeterli olamayacağı gibi; bir şiirin üzerinde gazel, kaside veya tahmis yazmasının da o eserin kıymetini yok etmeyeceğini savunur. Millîlik adı altında etrafına sekiz on çocuk toplamış üç dört kişinin, "sen edipsin, şairsin, dâhisin, üstatsın, lisan ve edebiyatımızın rükn-ü rasînisin!” (Mehmet Asaf 1334/1918: 42) sözleriyle bu çocukları şımartarak lisan ve edebiyatı bir çocuk oyuncağına dönüştürdüklerini söyler. Millî edebiyatı ilerletme ve geliştirme iddiasıyla yola çıkan bu gençlerin ise yüzyıllardır kullanılan aruz vezni, nazım biçimleri ve kelimeleri atarak dil ve edebiyatı üryan bıraktıklarını vurgular. Oysa lisan ve edebiyatın "mektep açar gibi, dükkân açar gibi birdenbire" (Mehmet Asaf 1334/1918: 43) tesis edilemeyeceğini ve asırlardan beri milletin hislerine tercümanlık etmiş dil ve edebiyatı birdenbire değiştirmenin mümkün olmadığını belirtir. Gençlerin hece vezniyle yazma ve bunları millî edebiyat ürünü olarak görme gayretlerini geçici bir gençlik hevesi olarak görür. Bu gençlerin demesiyle ya da istemesiyle aruz vezniyle yazmanın sona ermeyeceğini ifade eder. Metinde ileri sürdüğü bu tezi ise Süleyman Nazifin bir makalesinde geçen, "Cenap Şahabeddin'in ${ }^{6}$ yed-i hâkimiyetindeki kilk-i galip kolay kolay iskat edilemez." (Mehmet Asaf 1334/1918: 24) cümlesiyle destekler. Ayrıca Muhyittin Efendi gibi isimlerin lisan ve edebiyatı, doğru dürüst karar veremeyen birkaç çocuğun eline bırakmayacaklarına inandığını belirterek konuyu sonlandırır.

\title{
Eserin özeti
}

Oyun, Hayrettin Efendi ile eşi Afife Hanım'ın konuşmalarıyla başlar. Hayrettin Efendi, oğlu Mehmet Bey’in şiir yazdırmak için aşçıyı meşgul etmesinden şikâyet etmektedir. Çünkü Mehmet Bey’in Türkçe öğrenmek isteğiyle sürekli kendilerini rahatsız etmesinden dolayı son altı ay içerisinde on üç on dört aşçı işi bırakmıştır. Mehmet Bey tarafından işe alınan son aşçı ise hiçbir yemek ve tatlıyı Hayrettin Efendi'nin arzu ettiği güzellikte yapamamaktadır. Dolayısıyla istediği lezzette yemek yiyemeyen Hayrettin Efendi hem aşçının kalitesizliğine kızar hem de heba olan yemek malzemeleri için yaptığı masrafları hesaplar. Afife Hanım ise oğlunu savunur ve onun kötü bir huyu bulunmadığını belirtir. Karısının bu sözleriyle daha çok hiddetlenen Hayrettin Efendi, evin hizmetlisi Hanife'den Mesut'u çağırmasını ister. Mesut'un da oğlu Mehmet Bey ve aşçıyla birlikte mutfakta olduğunu öğrenince daha çok kızar. Odaya gelen Mesut

$6 \quad$ Cenap Şehabettin, Mehmet Asaf'ın dile getirdiği hece vezninin geçici bir heves olduğu fikrini savunan isimlerden biridir. Öyle ki Milli edebiyat akımını, Genç Kalemler dergisindeki yazarların havaya savurdukları bir balon olarak yorumlamıs ve "propaganda mahiyetinde" gördüğü bu hareketin "belki tecrübesiz ve yeteri kadar yetişmemiş gençleri bir müddetçik kendine çek[eceğine]”, fakat sonrasında etkisini kaybedeceğine inanmıştır (Ünaydın 2000: 79-80). 
kendine has üslubuyla mutfakta yaşananları anlatır. Hayrettin Efendi ile Mesut arasında, daha çok kelimelerin yanlış telaffuzuna dayalı bu diyalog, Şadan Bey’in geldiği haberiyle biter.

Şadan Bey'in gelişini memnuniyetle karşlayan Hayrettin Efendi, Mesut'a kendilerine birer kahve getirmesini söyler. Muhabbet bir müddet sonra Muallim Naci'ye ve şiir konusuna gelir. Onlar eski şiirin güzelliğini överken odaya elinde bir kâğıtla Mehmet Bey girer ve sevinçle aşçıbaşının aruz vezniyle de şiirler yazabildiğini söyler. Zaten yemek yapamadığı için aş̧̧ıaşına kızgın olan Hayrettin Efendi, oğlunun ısrarı üzerine şiiri dinlemeye ikna olur. Fakat aşçıbaşının şeftali, armut, şalgam gibi mutfak malzemeleriyle ve basit dilde yazdığı şiiri duyunca daha da hiddetlenir. Bunlara şiir denilemeyeceğini söyler. Babasının ithamları üzerine Mehmet Bey, bu şiirin dönem gazetelerinden biri olan Hanımlar Âlemi’nde yayımlandı ̆̆ını belirterek gazeteyi ve aşçıbaşını getirmeye gider. Şiirin gerçekten de gazetede yayımlandığını gören Hayrettin Efendi, oldukça şaşırır. Odaya gelen aşçıbaşı ise Mehmet Bey’in desteğiyle şiirini okur. Hayrettin Efendi, her dörtlükten sonra müdahale eder. Nitekim aşçıbaşı, şiirini okumayı bitirir.

Mehmet Bey ve aşçıbaşı odadan ayrıldıktan sonra Şadan Bey, Hanımlar Âlemi gazetesinin sahibinin alaycı bir kişi olduğunu ve bu tarz şiirleri dalga geçmek maksadıyla yayımladı̆̆ını söyler. Bu ikili, dönemin Muallim Naci'si olarak tanınan Muallim Muhyittin Efendi’nin bir şiirini okurlar ve asıl şiirin eski tarzda olduğuna kanaat ederler. Bu sohbet sonrasında Şadan Bey gider. Hayrettin Efendi ise lalanga yaparken aşçıyı oyalamasınlar diye Mehmet Bey ve Mesut'u mutfaktan uzaklaştırmak için odadan çıkar.

\section{Olay örgüsü}

Eserde tespit edilen başlıca metin halkaları şöyledir:

1- Hayrettin Efendi'nin, eşi Afife Hanım'a, şiir yazma hevesiyle aşçıyı oyalayan oğlu Mehmet Bey'den ve şiirle uğraşıp lezzetli yemek yapmayan aşçıbaşından dertlenmesi.

2- Şiir anlayışı bakımından Hayrettin Efendi ile aynı bakış açısına sahip Ali Şadan Bey'in ziyarete gelmesi.

3- Aşçıbaşının yazdığı ve gazetede yayımlanan bir şiirini okuması neticesinde Hayrettin Efendi ile Mehmet Bey'in eski ve yeni şiir anlayışı üzerine tartışmaları.

4- Odada yalnız kalan Hayrettin Efendi ile Şadan Bey'in okudukları bir şiirden hareketle aruzun güzelliğini savunmaları ve heceyle şiir yazma hevesindeki gençleri tenkit etmeleri.

Metin halkalarına bakıldığında oyunun genel olarak Hayrettin Efendi ve Mehmet Bey etrafında hecearuz/eski-yeni tartışması üzerine bina edildiği görülmektedir. Bu ana olayın yanı sıra eserde yer verilen yemek muhabbeti ise olaya güldürü katmak amacıyla kullanılmıştır.

Mehmet Asaf, oyunun serim kısmında oğlundan şikâyet eden bir baba ile oğlunu korumaya çalışan bir annenin konuşmalarına yer verir. Yazar, bu bölümde hem seyircide merak uyandırmayı hem de ilgi çekmeyi hedefler. Örneğin Hayrettin Efendi oyunun başında, bir taraftan oğlu Mehmet Bey'e diğer taraftan da aşçıbaşına kızar. Bu iki kişi arasındaki ilginç bağı açıklarken de mutfaktaki masrafları hesaplar. Böylece yazar, oyuna dikkat çekici bir giriş yapmaya ve oyunun öyküsünü seyirci açısından kısa bir sürede anlaşılabilir hâle getirmeye çalışır. Ayrıca Hayrettin Efendi'nin Mehmet Bey'e ve aşçıbaşına duyduğu kızgınlıktan bahsederek olayın devamını sağlayacak bir çatışma ekler. Çünkü "serim 
ancak çatışmalarla serpilir ve genişler" (Nutku 1998: 171). Dolayısıyla Mehmet Asafın serim kısmında dikkatini çekmeye çalıştı̆̆ı seyircinin ilgisini de canlı tutacak bir başlangıç yaptığı söylenebilir.

Beyimin Edebiyata Merakı oyununun çatışma kısmı, Hayrettin Efendi ve Şadan Bey grubu ile Mehmet Bey ve aşçıbaşı grubu arasında gerçekleşen münazaradır. Şiiri bir kültür meselesi olarak gören Hayrettin Efendi, aruz veznini kullanan ve sanat kaygısı taşıyan eski tarz şiirlerin ötelenip hece vezniyle gündelik basit konuları işleyen şiirler yazılmasına karşıdır. Ona göre, şairlik herkesin yapabileceği bir iş değildir. Mehmet Bey ise şiirin, halkın dilinden beslenen ve halkın yaşamını işleyen nitelikte olması gerektiğini ve bu yönüyle yeni tarzda yazılanların asıl şiir olduğunu savunur. Hatta aşçıbaşının bu tarzda yazdığı şiirlerin gazetelerde yayımlanacak kadar toplumdan kabul gördüğünü belirtir. Olay dizisini önceden belirtilen çatışma kurgusu üzerine inşa eden yazar, ikili arasındaki bu tartışmayı ara sıra diğer grup üyelerinin de katılımları ve örneklerle destekleyerek oyunu düğüm noktasına taşır.

“Hece mi arzu mu?”, “Şiir gündelik hayatı ve basit konuları ele almalı mı?” ve "Eski şiirler millî değil mi?” sorular üzerine düğümlenen oyun; Mehmet Bey, aşçıbaşı ve Mesut’un odadan çımasıyla baş başa kalan Hayrettin Efendi ve Şadan Bey'in konuşmalarıyla çözüme ulaştııılır. Oyun; asırlardan beri dil ve edebiyata mâl olmuş anlayışın bir anda değiştirilemeyeceği ve birkaç çocuk tarafından ortaya çıkarılan şeylerin şiir kabul edilemeyeceği hükmüyle sona erdirilir. Böylece Mehmet Asaf, oyunun kahramanları Hayrettin Efendi ve Şadan Bey aracılığıyla kendi sanat görüşünü de yansıtmış olur.

\section{Mekân/dekor}

Tiyatroda ele alınan olay tek bir yerde, Hayrettin Efendi'nin evindeki büyükçe bir odada geçer. Bu mekânın dekoru hakkındaki bilgi ise eserin başında "Perde" başlı̆̆ altında; "Alaturka tefriş edilmiş olan bu odada erkân minderlerinden maada üç, dört sandalye, kârı kadim bir kütüphane, üzerinde hokkalar, kalemler bulunan bir yazı masası vesaire dahi bulunur." cümlesiyle verilir. Dolayısıyla bu odadaki "alaturka" mefruşat ve eski zaman işi kütüphane gibi unsurlar, Hayrettin Efendi’nin muhafazakâr kişiliğiyle oldukça uyumludur. Ayrıca bu mekân/dekor seçimi, oyunun kolayca sahnelenmesine imkân sağlayacak niteliktedir.

\section{Zaman}

Beyimin Edebiyata Merakı adlı tiyatroda vaka zamanı, net olarak belirtilmese de birkaç saatlik bir zaman dilimini kapsar. Hayrettin Efendi’nin eşi Afife Hanım'la konuştuğu birinci meclisle başlayan eser, ziyaret için uğrayan Ali Şadan Bey'in bir müddet muhabbet ettikten sonra evden ayrılmasıyla sona erer. Eserde ele alınan sosyal zamanın ise oyunda bahsi geçen Hanımlar Âlemi gazetesinden hareketle, 19141918 yılları arasında olduğu söylenebilir. Ayrıca eser içerisinde hece-aruz tartışmalarının ele alınması, Millı̂ Edebiyat cereyanından söz edilmesi de dönem itibariyle bu tespiti destekleyen hususlardır.

\section{Şahıs kadrosu}

Dönemin edebî gündemlerinden olan hece-aruz ve edebiyatta millîlik tartışmalarını işlemek için kurgulanan bu oyundaki kahramanların bireysel özellikleri şöyledir:

Konevizade Hayrettin Efendi: Oyunun merkezî kişisidir. Bütün beyitleri "N" sesi ile bittiği için Kaside-i Nûniye olarak adlandırılan bir kaside kaleme alacak kadar eski edebiyat bilgisine ve sevgisine sahip biridir. Nitekim oyun başlarken Nedim Divanı okumaktadır. Altmış sekiz yaşındaki Hayrettin Efendi, eski edebiyatın yanı sıra yemeğe de oldukça düşkündür. Bu nedenle hem basit konularda ve hece 
vezniyle şiirler yazdığı için hem de güzel yemek yapmadığı için aşçıbaşına kızgındır. Asıl kızgınlığı ise bu aşçıbaşını işe alan ve şiir yazma hevesiyle sürekli aşçıyı oylayıp işini yapmasını engelleyen küçük oğlu Mehmet Bey'edir. Muallim Naci'nin sanat anlayışını benimseyen Hayrettin Efendi, sık sık ziyaretine gelen Ali Şadan Bey'le bu konularda dertleşmekte ve "Millî Edebiyat" adıyla ortaya çıkan şiir akımını eleştirmektedir.

Mehmet Bey: On sekiz yaşında genç bir delikanlıdır. Dönemin meşhur akımı olan Millî Edebiyat anlayışından etkilenmiş ve Türkçe şiirler yazma heyecanına kapılmıştır. Anadolu halkını yakından tanıma ve onların dilini öğrenme isteğiyle sürekli mutfağa gitmekte ve aşçlarla sohbet etmektedir. Onun bu ziyaretlerinden bunalan birçok aşçı işi bırakmış, evden ayrılmıştır. Mehmet Bey’in işe aldığı son aşçı ise doğru dürüst yemek yapamadığı gibi güzel şiir de yazamamaktadır. Fakat Mehmet Bey, saçma sapan da olsa onun hece vezniyle yazdığı şiirlerden etkilenmektedir. Dolayısıyla bu delikanlı, cahil ve heyecanlı kişiliğiyle "millî edebiyat hareketinin halka doğru ve millî vezin meselesini ifrat derecede benimseyen bir tip” (Yalçın 2002: 239) olarak oyunda yer alır.

Ali Şadan Bey: Otuz iki yaşında olmasına karşın Hayrettin Efendi'nin arkadaşıdır. Hayrettin Efendi'ye göre; eğitimli, zeki, uyanık ve terbiyeli bir gençtir. Şadan Bey de klasik edebiyatı ve aruz veznini savunmaktadır. Günlük gazete ve dergileri takip etmektedir. Millı̂ edebiyatı modası geçecek bir heves ve bu akıma gönül vermiş olanları da "kendisini zamanın cereyan-ı edebiyesine kaptırmış" çocuklar olarak görür. Bu anlamda yazarın Şadan Bey'e yüklediği görevin, yeni edebiyat anlayışına karşı klasik edebiyatı savunan Hayrettin Efendi’ye destek olmanın yanı sıra klasik şiir kültürünün "aklı başındaki” gençler arasında hâlâ varlığını sürdürdüğünü göstermek olduğu söylenebilir.

Aşçıbaşı: Yirmi bir yaşındaki bu genç aşçının ismi, Çınaroğlu Güdük Ahmet'tir. Aslen Boluludur. Evin küçük beyi Mehmet tarafından işe alınmıştır. Aslında iyi bir aşçı değildir. Fakat Türkçe kelimelerle ve hece vezniyle şiirler yazdı̆̆ı gerekçesiyle Mehmet Bey'in takdirini kazanmıştır. Oysa Hayrettin Bey, onun ne yemeklerini ne de şiirlerini beğenmektedir. Yazarın, tırnak içinde yazdığı açıklama kısımlarında onun sürekli sırıttığını vurgulaması, şiir diye yazdığı metinlerdeki saçmalığın farkında olduğu ve Mehmet Bey’in Millî edebiyat hevesinden istifade eden açıkgöz biri şeklinde hareket ettiği izlenimi vermektedir.

Afife Hanım: Hayrettin Efendi'nin eşidir. Oyunda çok fazla rolü yoktur. Sadece oyunun başlarında Hayrettin Efendi’nin suçlamaları karşısında annelik duygusuyla oğluna sahip çıkar. Eşi uzun uzun konuşup açıklama yaptığı hâlde o, genellikle kısa cümlelerle cevap verir. Oyundaki işlevi, Hayrettin Efendi’ye sorduğu sorularla olayın ve kahramanların seyirciye tanıtılmasına aracılık etmek gibidir.

Mesut Ağa: On dokuz yaşındaki Arap köledir. Mehmet Bey ve aşçıbaşının mutfaktaki konuşmalarını Hayrettin Efendi'ye anlatırken kendine has üslubu ve yanlış telaffuzlarıyla oyuna güldürü katar.

Hanife: Evin hizmetçisidir. Oyundaki görevi, Hayrettin Efendi’nin isteği üzerine mutfaktan Mesut’u çağırmak ve Ali Şadan Bey’in geldiğini haber vermekten ibarettir.

Görüldüğü üzere oyundaki şahıs kadrosu çok geniş değildir. Bir ev ortamında geçen oyunun kahramanları; anne, baba, oğul, hizmetçiler ve bir misafirden ibaret yedi kişiden oluşmaktadır. Olaylar ise daha çok Hayrettin Efendi ile oğlu Mehmet Bey'in edebiyat anlayışları arasındaki çatışmaya dayanmaktadır. Bu bağlamda oyundaki şahısları şu şekilde gruplandırmak mümkündür: Klasik edebiyat anlayışını savunan Hayrettin Efendi ile Ali Şadan Bey ve Millî edebiyat anlayışını savunan Mehmet Bey ile aşçıbaşı. Bu ikiliden etkilenen Mesut ile annelik duygusuyla oğluna arka çıkan Afife Hanım da bu 
gruba dâhil edilebilir. Oyunda çok fazla rol almayan Hanife ise tartışmalarla ilgili herhangi bir beyanı bulunmaması yönüyle bağımsızdır.

\section{Oyundaki dil ve anlatım}

Mehmet Asaf, Beyimin Edebiyata Merakı adlı bu oyununda kahramanlarını dönemin yaşayan, günlük diliyle konuşturur. Aynı zamanda kişilerin millî ve kültürel özelliklerine dikkat eder. Mesela Ali Şadan Bey ile Hayrettin Efendi’nin muhabbetlerinde Arapça, Farsça kelime ve tamlamalara yer vererek onların eğitim durumlarını ve ilgi alanlarını ortaya koyar. Aşçıbaşını konuştururken ise çok daha sade bir dil, başka bir ifadeyle Anadolu Türkçesi kullanır. Ayrıca Arap bir köle olan Mesut'u konuştururken onun yaşadığı telaffuz zorluğuna değinir. Böylece yazar bilinçli bir şekilde, Mesut’un yanlış telaffuzlarıyla oyuna bir taraftan güldürü katarken diğer taraftan kahramanları kimliklerine uygun dillerle konuşturarak canlandırılan olaya gerçeklik hissi kazandırmaya çalışır.

Yazar, oyunu kaleme alırken üslup konusunda da bilinçli hareket etmiş ve oyunu oluştururken rahatça anlaşılabilecek kısalıkta cümleler kullanmıştır. Böyle sade ve anlaşılır bir üslup kullanmasında yazarın gazetecilikten gelen halka hitap etme deneyiminin etkili olduğu düşünülebilir. Bunun yanında yazarın dil ve anlatım konusunda bazı küçük eksikliklerinden de bahsedilebilir. Örneğin oyun metnini yazarken cümlelerdeki vurguyu noktalama işaretleriyle desteklemeye çalışmış; fakat bazı yerlerde noktalama işaretlerini ya hiç kullanmamış ya da genel kuralların dışında kullanmıştır. Mesela birçok yerde üç nokta yerine iki nokta (..) kullanmıştır. Metnin Latin alfabesine aktarılması sırasında da kahramanların konuşmalarından önce kullanılan iki nokta (:) ile özel isimlere gelen çekim eklerini ayıran kesme işaretleri haricinde yazarın noktalama işareti tercihlerine riayet edilmiştir. Ayrıca metnin aktarımı sırasında genel olarak Türk Dil Kurumunun güncel yazım kuralları esas alınmış, ancak Güncel Türkçe Sözlük’te olmayan kelimeler ile aruz vezniyle verilen şiirler, Arapça/Farsça ses yapısına göre yazılmıştır.

\section{Sonuç}

Türk siyasî ve sosyal tarihinin birçok dönemine şahitlik eden Mehmet Asaf, birçok gazete ve dergide yazarlık, başyazarlık yapması ve idari görevler üstlenmesi sebebiyle Türk kültür tarihinde daha ziyade gazeteciliği ile tanınmıştır. Fakat o, gazeteciliğin yanı sıra şiir, roman ve tiyatro gibi değişik birçok türde eser kaleme almış ve bunlardan otuz kadarını kitap olarak yayınlamıştır. Bu makalede ele alınan Beyimin Edebiyata Merakı adlı tiyatro oyunu da bu eserlerden biridir.

Beyimin Edebiyata Merakı adlı tiyatro oyunun dikkat çeken yönlerinden birisi, 1918'de yani Birinci Dünya Savaşı'nın bittiği veya bitmek üzere olduğu bir dönemde yayınlanmasına rağmen dönemin sosyal ve siyasî olaylarından hiç bahsetmemesidir. Bu durum, aslında gazete yazılarında sosyal ve siyasî yazılara yer veren Mehmet Asaf’n, tiyatronun sınırlılıklarının farkındalığıyla konuyu dağıtmamak düşüncesinin neticesi olarak yorumlanabilir.

Mehmet Asaf, komedi türünde kaleme aldığı bu tiyatro oyununda, dönem itibariyle etkisini hissettiren hece-aruz tartışması, şiirde muhteva, şiirde eskilik-yenilik, şiir dilinin sadeleşmesi ve edebiyatta millîlik gibi konulara değinir. Hece vezni ve halk diliyle yazılmışs şiirleri savunup aruz vezni ve Arapça/Farsça kelimelerle yazılmış eski şiirleri reddeden dönemin popüler edebiyat akımı Millî Edebiyat anlayışına karşı çıkar. Bir şiirin, sırf hece vezni kullanıldığı, basit kelimeler içerdiği, köy ve köylüden bahsettiği için millî kabul edilip bunun haricindeki şiirlerin ise gayrı-millî görülüp ötelenmesini doğru bulmaz. Zira Mehmet Asaf şiirde ses, ahenk, ritim gibi estetik unsurları ile muhtevada bütünlük arar. Dolayısıyla 
sanat ve estetikten uzak gördüğü Millî Edebiyat akımını, gençler arasında dolaşan geçici bir heves olarak yorumlar. Bu düşüncesini de oyunda kendi sözcüsü gibi kurguladığı kahramanlar vasıtasıyla dile getirir. Oyuna gerçeklik hissi kazandırmak için ise oyun içerisinde Nefî, Muallim Naci, Mehmet Celal, Veysî, Nergisî, Cenap Şahabettin, Süleyman Nazif, Faik Ali, Recaizade Mahmut Ekrem, Tevfik Fikret ve İsmail Safa gibi konuyla bağlantılı gerçek isimlerden bahseder. Böylece bu tartışmalardaki farklı isimlerin görüşlerini dile getirerek hem konuya açıklık getirmeyi hem de okurun/seyircinin ilgisini çekmeyi hedeflediği söylenebilir. Netice itibariyle, genelde gazeteciliğiyle tanınan Mehmet Asaf'ın edebî eserlerinin de yazıldıkları dönemi farklı açlardan yansıtan ürünler olduğu ortadadır. Dolayısıyla Türk edebiyat tarihine katkı sağlamak adına bu eserlerin de günümüz alfabesine aktarılması ve üzerlerinde çalışmalar yapılması gerekmektedir. 


\section{BEYIMIN EDEBİYATA MERAKI}

Gülünçlü Komedi 1 Perde

Muharrir: Mehmet Asaf

Tiyatroda vaz' hakkı muharririndir

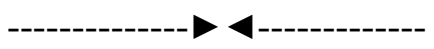

Naşiri:

Cemiyet Kütüphanesi

Dersaadet

[Matbaa-i Orhaniye]

1334

\section{BEYIMIN EDEBIYYATA MERAKI}

Gülünçlü Komedi 1 Perde

Komedinin Kahramanı: Gözlemecioğlu Mehmet Bey

1334

Necm-i İstikbal Matbaası

Tab'-ı Naşiri: Cemiyet Kütüphanesi 


\section{Eşhas}

Konevizade Hayrettin Efendi

Mehmet Bey (Gözlemecioğlu)

Ali Şadan Bey

mezunlarından, 32 yaşında

Mesut Ağa

yaşında

Çınaroğlu Güdük Ahmet

Afife Hanım

zevcesi

Hanife

Hizmetçi, 28 yaşında
Kaside-i Nuniyye sahibi, 68 yaşında

Mahdumu, 18 yaşında

Fikretiye Mektebi

Arap köle... 19

Aşçıaş̧ı

Hayrettin Efendi'nin

\section{Perde}

Hayrettin Efendi'nin hanesinde büyükçe bir oda irae eder. Alaturka tefriş edilmiş olan bu odada erkân minderlerinden maada üç, dört sandalye, kâr-ı kadim bir kütüphane, üzerinde hokkalar, kalemler bulunan bir yazı masası vesaire dahi bulunur. Hayrettin Efendi yüksek bir minder üzerinde bağdaş kurmuş olduğu hâlde hiddetli hiddetli söylenir. Zevcesi Afife Hanım da karşısında bir sandalyede oturmuş olduğu hâlde görünür.

\section{Birinci Meclis}

Hayrettin Efendi, Afife Hanım- sonra Hanife ve Mesut

Hayrettin Efendi: (Okuduğu Nedim Divanı'nı yanına bırakarak) Olmaz efendim. Bu, çekilir dert değil... Bir, iki, üç... Nedir bu artık... Böyle evlat olacağına olmaz olaydı... İki kız, bir oğlan öyle gürleyip gitti. Hayr-ül-halef olsun diye ahir vaktimde bunu peyda ettim. Hay etmez olaydım... Hayr-ül-halef nerede... Musibet; şerr-ül-halef olacak...

Afife Hanım: Doğrusunu isterseniz o kadar meraklanmaya hakkınız yok... Çocuğun ne fenalığını görüyorsunuz? Tütünü mü var? İçki içiyor da zil zurna mı oluyor? Yoksa karşıda kötü sokaklarda mı dolaşıyor? (Kendi kendine) İnsanlar acayiptir. Tütün içse, tütün içiyor derler kabahat olur. Rakı içse sarhoş derler. Beyoğlu'na gitse gezse çapkın derler. Hâlbuki zavallı çocuğun bir şey yaptığı yok... Kabahati ne imiş? Okuyor, yazıyormuş... Fesuphanallah...

Hayrettin Efendi: Böyle okumak yazmak eksik olsun! Okuyup yazıyormuş.. Mektebe mi gidiyor? Hayır.... Ya ne yapıyor? Şiir söylüyor. Şair olacakmış... Beyimin edebiyata merakı varmış... (İstihfafkârane gülerek) Edebiyat; o, başka fen, başka ilim... Pınardan testi dolduran köylü kızını, ayran çanağını başına diken Memo'yu, yamaçlarda kaval çalan çobanı bize yabancı bir lisan ile, ağlak ve iphama boğarak tasvir etmek edebiyattan ma'dûd olsaydı bütün dünya edip, beliğ, şair kesilirdi. Anlıyor musun kadınım! Senin çocuğunun okuyup yazması boş... Neme lazım ister boş olsun, ister dolu... Mini mini çocuk değil a! On sekizini bitirmek üzere... Mademki başa çıkamıyorum. Allah müstahakını versin der bırakırım. Fakat keyfime dokunmasa...

Afife Hanım: Keyfinize dokunup da ne yapıyor? 
Hayrettin Efendi: (Hiddetlenerek) Daha ne yapacak? Her gün zarar her gün ziyan... Şekeri yüz doksana, halis baklavalık Romanya ununu yüze alıyorum. Halep yağının on üç okkalık bir tenekesine kırk bir lira verdim. Yarım lira daha verseydim kırk bir buçuk maşallah deyip çıkacaktım. Bu kadar masrafa karşı ağız tadıyla bir lalanga, tulumba tatlısı yemek nasip oluyor mu? Aşçının evvelki gece yaptığı alt üst böreği gördük? Niçin beğenip de yemedik? Ama haklısın! Yenilir şey miydi o? Börek değil, pabuç köselesi...

Afife Hanım: Aşçı böreği iyi yapamadıysa çocuğun ne kabahati var?

Hayrettin Efendi: Ne kabahati mi var? Asıl kabahat onun... Hem de kabahatin büyügüu... Gelen aşçlara rahat mı veriyor? Altı ay içinde on üç on dört aşçı oldu. Hangisi beş günden, nihayet bir haftadan ziyade oturabildi? Aman yandık, çıldıracağız diye çıkıp gittiler. Bizim evden adeta canlarını kurtardılar. Yerden göğe kadar hakları var. Oğlan mutfaktan dışarı çıkmadı ki... Sabah, akşam heriflerin başında... Bana Türkçe öğreteceksiniz diye yapmadığı kalmadı. Her giden aşçı geldi, benimle vedalaşırken efendi senden hoşnudum, Allah da hoşnut olsun, fakat küçük beyin kahrını çekemeyeceğiz diyerek çıkıp gittiler.

Afife Hanım: Mademki öyle imiş de bu aşçıbaşı iki aya yakın bir zamandır niçin oturuyor?

Hayrettin Efendi: Kadınım! Senin aşçıbaşı dediğin; aşçıların başı değil kuyruğu bile olmaz. Bu; yaptığı yemeklerle sabit... Börek, tatlı nerede, bulgur pilavını bile adam akıllı pişiremiyor. Söylemeye ne hacet! Sen de her gün, her gece görüyorsun... Dün akşam pişirip de verdiği ıspanak kavurmasını zorla yedik... Hâlbuki harcını, masrafını tamam veriyoruz. Yağı âlâ Halep... Soğanı bol... Niçin yiyemedik? Çünkü yenilir gibi değildi. Sebebi aşçının maharetsizliği, acemiliği... Ama ne olacak yirmi bir yaşındaki aşçı yamağından da bundan başka ne beklenir?

Afife Hanım: Ispanak kavurmasını erkek aşçıları zaten iyi yapamazlar.

Hayrettin Efendi: Peki öyle olsun, kabul edelim. Ya üç gün evvelki yalancı dolmaya ne buyurursunuz.

Afife Hanım: Yenmeyecek gibi mi idi ya?

Hayrettin Efendi: Yedik ama zorla... Ben bu şeker kahtında ona şeker veriyorsam cüz’i koysun da yemeklerin tadı gelsin diye veriyorum. Hâlbuki o doldurmuş şekeri... Soğanı da haddinden fazla kaçmış, olmuş sana bir yalancı dolma reçeli... Koy bir zarif tabak içine, güzelce istif et! Ondan sonra götür, Havyar Hanı sırasındaki tatlıcının camekânına oturt! Üzerine de yalancı dolma reçeli diye yaz! Doğru değil mi?

Afife Hanım: Zaten siz her şeye bahane bulursunuz?

Hayrettin Efendi: (Yine hiddetlenerek) Şimdiye kadar neye bahane buldum acaba? Bundan evvelki aşçıdan şikâyetim var mıydı? İki söz söylediğimi işittin mi? Yaptığı o, katmerli gözlemelere, ince böreklere karşı ne diyebilirdim? Hâlbuki yüz doksana şeker, yüze Romanya unu al! Yağın tenekesine kırk şu kadar lira ver! Sonra da ağız tadıyla bir tatlı yiyeme! Hele iki lakırtı söyledin mi; her şeye bahane bulursun diye sana itap etsinler... Yook... Doğrusu çekemeyeceğim.

(Yanındaki enfiye kutusunun kapağını açıp bir tutam çektikten ve üç kere de aksırdıktan sonra) Aşçıdan Türkçe öğrenecekmiş de hece vezniyle şiir söyleyecekmiş... Ne halt eder ağanın barkiri... Şu dar zamanda 
ben bu kadar masraf edeyim. Sonra sofradan aç kalkayım... Ne maskaralık bu... Beyimin edebiyata merakı varmış. Hay olmaz olaydı...

(Ellerini birbirine vurarak dışarıdan birini çağııır) Kim var orada?

Afife Hanım: Kimi istedinizdi?

Hayrettin Efendi: Merak ettim. Oğlan nerede? Mesut meydanda yok... (Yine ellerini vurarak haykırır) Kim var orada?

Hanife: (İçeriye girer) Bir emriniz mi var efendim?

Hayrettin Efendi: Küçük Bey nerede?

Hanife: Mutfakta, aşçıbaşının yanında...

Hayrettin Efendi: Nerede olacak? Sormak abes... Mutfaktan başka nereye gidecek? Mesut nerede?

Hanife: O da mutfakta efendim...

Hayrettin Efendi: (Hiddetlenerek) Al bir maskaralık daha... İster misiniz Arap’a da şiir merakını sardırsinlar... Sonra o da:

Dingala kabak dingala

Kömür koymuş mangala

de hem kafiye vardır, hem de vezin diyerek ortaya çıssın!

(Hanife'ye) Git seslen! Mesut buraya gelsin!

Hanife: Peki efendim (Çıkar)

Hayrettin Efendi: (Afife Hanım'a) Benim aklıma gelen başıma da gelir. Bu aşçı ile oğlan; Arap’a da şiir merakını sardıracaklar... Dikkat ediyorum. Sekiz on gündür Mesut'un da mutfaktan çıktığı yok.. (Mesut içeriye girer)

Mesut: (Kendi şivesiyle) Beni çağırdınız mı efendim?

Hayrettin Efendi: (Yine enfiyesini çekip üç kere aksırdıktan ve büyük mendiliyle burnunu ve sakalını sildikten sonra) Çağırdım. Nerede idin?

Mesut: Küçük Beyisi ile mutfakta idik.

Hayrettin Efendi: Mutfakta ne yapiyordunuz?

Mesut: Ben bir şey yapmadı. Küçük Beyisi ile aşçıbaşı edebiyatını yapıyordular.

Hayrettin Efendi: Ne yapıyorlar, ne yapiyorlar?

Mesut: Edebiyatını yapıyorlar. Vezneli, vakfiyeli lakırtılar uyduruyorlar. 
Hayrettin Efendi: (Afife Hanım'a hitaben) Gördün mü maskaralığın derecesini? Şiir; Arap'ın ağzında bak neler oluyor. Vezneli, vakfiyeli edebiyat imiş. (Kendi kendine) Zavallı vezin, zavallı kafiye! Hususiyle zavallı şiir...

Mesut: Aşçıbaşı çok güzel şiirlerini yapıyor. Parmaklı şiirlerini bile uyduruyor. Küçük Beyisi çok hoşlanıyor, seviniyor (Ellerini çırpar gibi yaparak) böyle böyle yapıyor.

Hayrettin Efendi: Nasıl nasıl? Parmaklı şiirler mi!

Mesut: (Gülerek) Parmaklı mı, parmaklıklı mı işte öyle şeyler yapıyor.

Hayrettin Efendi: Anladım, şimdi anladım. Parmak hesabıyla olacak.

Mesut: Evet efendim evet... İşte öyle parmaklıklı hesabıyla... Hem o parmaklıklı hesaplı edebiyatını hanımlarına da yazdırmışlar.

Hayrettin Efendi: (Anlamayarak) Hanımlar da mı yazıyormuş?

Mesut: Hanımlarına değil... Hanımlarının bir gazetesi varmış da...

Hayrettin Efendi: Hanımlar Âlemi mi?

Mesut: İşte o, işte o... Hanımlarısının Âlemi...

Hayrettin Efendi: Anladım... Hanımlar Âlemi... Bu gazeteye ne olmuş?..

Mesut: (Anlatmaya çalışarak) Gazetesine bir şey olmamış... Aşçıbaşı edebiyatını hanımlarına âlemine gazetesine bastırmış...

Hayrettin Efendi: (Hiddetle yerinden firlayarak) Bu, ne kepazelik... Bu, ne maskaralık... (Mesut'a hitaben) Hanımlar Âlemi gazetesi aşçının şiirlerini mi dercetmiş?

Mesut: (Yine anlatmaya çalışarak) Hanımlarına âlemine gazetesi aşçıbaşının vakfiyeli, vezneli...

Hayrettin Efendi: (Haykırarak) Beni günaha, belaya uğratma! Kafiyeye vakfiye deyip durma!

Mesut: (Şaşırarak) Ben demedi... Küçük Beyisi ile aşçıbaşı öyle diyorlar.

Hayrettin Efendi: Kim derse desin halt etmiş...

Mesut: Küçük Beyisi öyle söylüyor.

Hayrettin Efendi: Doğru dürüst anlat! Hanımlar Âlemi gazetesi aşçının şiirlerini mi koymuş...

Mesut:Aşçıbaşının vezneli edebiya...

Hayrettin Efendi: (Yine haykırarak) Vezneyi, vakfiyeyi kaldır... Aman ne kadar da sinirime dokunuyor bu lakırtı... 
Mesut: Veznesiz, vakfiyesiz edebiyatını olur mu?

Hayrettin Efendi: (Hiddetlenerek) Bu çetrefil Arap’a da merak anlatmak ne kadar müşkül... Oğlum! Ona vezne, vakfiye demezler...

Mesut: (Anlamış gibi görünerek) Anladım efendim anladım... Ben yanlış söylüyorum vezneli edebiyat değil, vezneciler edebiyatı olacak...

Hayrettin Efendi: (Hiddetlenerek kendi kendine) Çıldıracağım şimdi... Yarab! Sen bana sabır ihsan buyur! Vezneli edebiyat derken Arap; işi vezneciler edebiyatına döktü (Yine bir enfiye çekip aksırarak) vezneli edebiyat, vezneciler edebiyatı olmaz...

Mesut: Ha! Öyle mi? Belki vezneciler edebiyatı değildir. (Ciddiyetle) Efendi! Sakın Direklerarası edebiyatı olmasin!

Hayrettin Efendi:(Haykırarak) Defol karşımdan... Beni günaha sokup durma! Vezneciler’in, Direklerarası'nın edebiyatı ne demek... Çattık belaya... (Bu aralık Hanife girer.)

Afife Hanım: (Hanife'ye) Ne var?

Hanife: Bir bey gelmiş... Efendiyi görmek istiyor.

Hayrettin Efendi: Nasıl beymiş o?

Hanife: Geçen gün de gelmişti. Zaten her zaman gelir. Genç...

Hayrettin Efendi: Anladım, anladım. Ali Şadan Bey... Haydi Mesut! Çabuk, buyurundu!

Afife Hanım: Biz çıkalım (Hanife ile çıkarlar.)

Mesut: Peki efendim (Gider. İki dakika sonra Ali Şadan Bey önde, Mesut arkada içeriye girerler)

\section{İkinci Meclis}

Hayrettin Efendi, Ali Şadan Bey, Mesut

Hayrettin Efendi: (Ayağa kalkarak) Buyurun efendim! Buyurun!

Şadan Bey: (Yerden temenna ederek) Allah ömürler versin efendim!

Hayrettin Efendi: (Yer göstererek) Şöyle buyurun beyim!

Şadan Bey: Teşekkür ederim efendim (Oturur)

Hayrettin Efendi: (İstifsarıhatır ederek) İnşallah afiyettesiniz efendim!

Şadan Bey: Çok şükür efendim. Sizler de afiyettesiniz inşallah 
Hayrettin Efendi: Zamanın iyiliği malum... İnsan her dakika hırs ve hiddet içinde kalıyor. (Mesut'a hitaben) Haydi bize birer kahve... Beyefendi şekerli içerler.

Mesut: Peki efendim!

Hayrettin Efendi: (Mesut çıkacağı sırada) Mesut! Bana da bir şekerli yap!

Mesut: Baş üstüne efendim (Mesut çıkar)

Şadan Bey: Efendim! Bugün sizi pek hiddetli görüyorum.

Hayrettin Efendi: Hiddetlenmemek kabil mi beyim? Yüz doksana şeker, yüz kuruşa Romanya unu al! Halep yağının tenekesine kırk bir lira ver! Sonra da ahir vaktimde ağız tadıyla bir lalanga, gözleme, tulumba tatlısı yiyeme! Çekilir dert mi bu efendim?

Şadan Bey: Şikâyetiniz neden peder efendi hazretleri? Unlar mı fena? Yoksa şekerlerin mi kuvveti yok?..

Hayrettin Efendi: Şekerler aliyyülâlâ... Hele aldığım unlar halis baklavalık... Halep dersen birinci haddeydi...

Şadan Bey: Bunlardan başka sebepler var demek?

Hayrettin Efendi: (Enfiye kutusunu Şadan Bey’e uzatarak) Öyle bir sebep ki..

Şadan Bey: Kulunuz enfiye istimal etmem.

Hayrettin Efendi: Gerçek kullanmazdınız. Maşallah sizin sigaranız, içkiniz de yoktur değil mi?

Şadan Bey: Evet efendim... Çok şükür itiyat etmemişim...

Hayrettin Efendi: (Memnunâne) Oh, oh... Çok şükür, maşallah... Ya şu zamanda bir de tütün, içki derdi olsaydı... Bu belalardan ben de varesteyim ya... İşte yalnız enfiye... Ona da kalemde iken alışmıştım. Bir mümeyyizimiz vardı, Hakk rahmet eylesin... Tütünü, içkisi falan yok... Fakat enfiye dediniz mi? Tiryakisi.... Nerede o zamanki enfiyeler... Gül kokulusu, menekşelisi, daha birçok envâı... Dediğim kırk beş senelik şey.... O zaman ben evkafin cihat kaleminde idim. Demin arz ettiğim mümeyyizimiz, Cenabıhak rahmet-i sübhaniyyesine mazhar buyursun, pek hoşgû bir zat idi. Hani ya yabana atmayın! Erbab-ı kalemden idi... Nef'iyâne birçok gazelleri vardı. Fakat neşretmezdi. Şair İsmet Efendi merhum o zamanlar Ceride-i Havadis'te idi. Hemen her gün matbaada toplaşırdık. Ne âlemler idi o ne âlemler...

Şadan Bey: Muallim Naci merhumla da muarefeniz var mıydı efendim? (Bu esnada Mesut elinde kahve tepsisi olduğu halde girer ve fincanın birini Şadan Bey'e vermek ister. Şadan Bey ise Hayrettin Efendi'yi irae eder)

Hayrettin Efendi: Buyur evladım. Teklifle mi fincan alacağız?

Şadan Bey: (Mahcubane) Aman efendim ayıp olmaz mı? (Fincanı alır. Mesut diğer fincanı da Hayrettin Efendi'ye vererek elinde tepsi, kenarda durur) 
Hayrettin Efendi: «Kahveyi içerek» Muallim merhumla muarefemizden bahis buyurdunuz. Muarefe değil aramızda bir rabıta-i samimiye vardı. Cidden sevişirdik. Yalnız bir noktada ayrılırdık. Ben müskirattan müteneffir idim. Hâlbuki o müptela-i işret idi. Zaten genç yaşında kurban-ı işret olup gitti ya. (İçini çekerek) Ah bilmezsin yavrum, bilmezsin beyim. Naci Bey büyük bir adam idi. Osmanlı lisan ve edebiyatına ettiği hizmet kabil-i inkâr mıdır? Ama inkâr ediyorlarmış. Varsınlar etsinler. Hatta vefatından sonra mezar taşlamak kabilinden aleyhinde yazılmadık, söylenmedik söz kalmadı. Hâlbuki bugün Kuzu, Sehâbe, Kebûter gibi bir manzume yazacak varsa parmak kaldırsın. Görüyoruz. Şiir, nesir, hikâye namları altında ortaya çıkarılan mahsulat-ı kalemiyeyi görüyoruz. Bugünün şiirinde sorarım size bir zevk buluyor musunuz? Ne vezin var, ne kafiye... Bundan bilmem kaç sene evvel Mehmet Celâl merhum:

Şiirin ne tuhaf kalmadı hiç zevki, usulü Halkın kimi Verlaine, kimi Âşılk Ömer oldu

demişti. Şimdi Verlaine'lik falan da kalmadı. Hece vezniyle şiir.. Masal kabilinden roman, yahut hikâye... Biraz daha gayret edilirse saz kahveleri ihya edilecek, sonra bir de Veysî, Nergisî neşirlerinin kaside, gazel tarzının avdet edeceğinden korkuyorlar.. Acaba bir şiirin, bir bedianın üstüne gazel, kaside, tahmis konulmakla o eserin, o bedianın kıymetinden düşmesi mi lazım gelir? Yoksa o unvanlı eş’âr mutlaka kıymetsiz midir? «Kahveler içilir. Fincanları Mesut alıp çıkar»

Şadan Bey: Hakk-ı âlîniz var efendim.

Hayrettin Efendi: Bugün beni hiddetli gördüğünüzü demin söylüyordunuz. Nasıl hiddetlenmeyim. Bir taraftan lisan ve edebiyat bâzîçe-i etfâl olup gidiyor. Diğer taraftan bana ağız tadıyla bir gözleme, bir lalanga yemek nasip olmuyor. Yüz doksana şeker, yüz kuruşa Romanya unu alırken bile.

Şadan Bey: Aff-ı âlîlerine mağrûren soracă̆ım: Lisan ve edebiyat ile gözleme, lalanga, yahut alt üst börek arasında ne münasebet var efendim? «Bu sırada Mehmet Bey elinde bir kâğıt olduğu halde gülerek, sevinerek içeriye girer. Onu müteakip Mesut da gelir»

\section{Üçüncü Meclis}

\section{Evvelkiler - Mehmet Bey}

Mehmet Bey: «Hayrettin Efendi’ye hitaben» Efendibaba. Aşçıbaşı aruz vezniyle de Türkçe şiir söylüyor.

Hayrettin Efendi: «Şadan Bey’e hitaben» Benim izahat vermekliğime artık hacet kalmayacak. Lisan ve edebiyat ile gözleme, lalanga, börek arasındaki münasebeti şimdi anlayacaksınız?

Mehmet Bey: Rica ederim efendibaba dinleyiniz! Bakınız! Aruz vezniyle de ne güzel şiir söyleniyor. Fakat bu, yalnız bizim aşçıbaşıya mahsus..

Hayrettin Efendi: «Hiddetle» Bıktım bu soğuk maskaralıktan.. Oku bakalım.

Mehmet Bey: «Memnunâne» Bakınız, göreceksiniz ya, pek beğeneceksiniz.

Hayrettin Efendi: Haydi? Uzun etme de oku. 
Mehmet Bey: İşte okuyorum. «Elindeki kâğıda bakarak okur.»

Yarma şeftali sepetinden düştü al benden haber

Suluca armut yerine kimse şalgam istemez.

Hayrettin Efendi: «Hiddetle» Çekil karşımdan... Beni günaha, belaya sokma!

Mehmet Bey: Fakat efendim, işte bu aruz vezniyledir. Bunu da beğenmedikten sonra...

Hayrettin Efendi: «Şadan Bey’e» Anladınız mı? Lisan ve edebiyat ile lalanga, tulumba tatlısı arasındaki münasebeti artık keşfettiniz ya?

Şadan Bey: «Hayretle» Lakin efendim af buyurunuz! Anlayamıyorum. Lisan ile edebiyat, gözleme ile lalanga... Bunlar ayrı ayrı şeyler...

Hayrettin Efendi: Şimdi ayrı ayrı şeyler değil... Evvelce ayrı ayrı şeyler idi. Şiirin vezni, kafiyesi, ahengi, nikâtı, nikât-ı nâzikesi, velhasıl her şeyi var idi. Edebiyat bir başka fen, bir başka ilim idi. Erbab1 kalem; terbiyet-âmûz ümem idi. Herkes şair olamaz idi. Şimdi ise her önüne gelen muharrir, şair, hatta dâhi... bir kaval, iki çoban, bir yamaç, bir dere kenarı yan yana konuldu mu çıkıyor ortaya bir şiir.... Şiir ama ne şiir....

Şadan Bey: Hakk-ı âlîniz var efendim... Bir kaval, iki çoban yan yana getirildi mi ortaya ya bir şiir, yahut bir hikâye çıkıyor. Sonra da buna «Millî edebiyat» diyorlar.

Hayrettin Efendi: Buna bir de hece veznini ilave ettiniz mi artık ortaya bir «şaheser» çıkıyor.

Mehmet Bey: «Sandalyeye oturarak» Lakin efendibaba! Kadirşinaslık ediyorsunuz! Bugün bütün gençler Millî edebiyatın terakkisine, tealisine, inkişafına çalışıyorlarken...

Hayrettin Efendi: «Şadan Bey'e» Görüyor musunuz bizim mahdum beyi... Bütün gençlerin Millî edebiyatın terakkisine, inkişafına çalıştıklarından dem vuruyor. Allah aşkına oğlum! Şu cahil çocuğu biraz irşat et!

Şadan Bey: Estağfurullah efendim... İrşat ne demek... Kendileri benim irşadıma muhtaç mıdırlar ki... Fakat herhalde efendim, şunu arz etmek isterim ki bugüne kadar yazılmış olan şiirler ve nesirler, velhasıl bütün mahsulat-ı edebiyye; bizim malımız, bizim tercüman-ı his ve efkârımız değil de başkasının malı, başkasının tercüman-ı his ve efkârı mıdır?

Mehmet Bey: Fakat efendim, müsaade buyurunuz da

Hayrettin Efendi: «Mehmet Bey’e hitaben» Dur biraz... Beyefendi sözünü ikmal etsin de...

Şadan Bey: Evet efendim... Cenap’nn, Süleyman Nazifin, Faik Ali’nin asarı Millî Edebiyatın haricinde midir? Hem efendim rica ederim, edebiyatın, millîsi, ecnebisi ne oluyor? Aruz vezniyle ifade edilen hissiyat ve efkâr Boğaz'ın mavi suları üstünde uçan kotraları, Ada'da bir levha-i gurubu, Rumeli Hisarı'nda bir şeb-i mehtâbı musavver olan bedayi-i edebiyye niçin ecnebi addediliyor da sonra Bolu Sancağının Mengen Kazasındaki bilmem ne köyünde pınardan testisini doldururken yamaçta kaval çalan çobana bir nigâh-ı iştiyâk firlatan köylü kızını musavver olan sözler ve yazılar millî sayıllyor? 
Mehmet Bey: Bakınız efendim... Şunu arz edeyim...

Hayrettin Efendi: «Sözünü keserek» Dur diyorum sana.. Beyefendi sözünü ikmal etsin de...

Mehmet Bey: Lakin efendibaba! Ben de iki söz söylemek isterim... (Mehmet Bey hiddetle ayağa kalkar ve hiddetle odadan çıkar)

Hayrettin Efendi: Gördünüz mü yaptığı maskaralığı? Aşçıbaşı aruz vezniyle de Türkçe şiir söylermiş... Yarma şeftali sepetten düşmüş de.., armut suluca imiş de.., velhasıl bir sürü kepazelik...

Şadan Bey: Küçük beyi kızdırdınız efendim!

Hayrettin Efendi: Ne halt ederse etsin... Benim hezeyan, yave dinlemeye vaktim yok.. Hem efendim meraklanıyorum, elimde değil... Ben bu kadar şeker, un, yă̆ parası vereyim, sonra da ahir vaktimde istediğim gibi güzel bir tatlı yemeyeyim... Olur mu hiç? Buna nasıl tahammül edilir. (Enfiyesini çekip aksırdıktan sonra) Haklı değil miyim evladım? Allah için söyle!

Şadan Bey: Gerçi hakk-ı âlîniz derkâr... Fakat ne denir çocukluk.. Kendisini zamanın cereyan-ı edebiyyesine kaptırmış...

Hayrettin Efendi: Çocukluk mu? On sekizini bitiriyor.

Şadan Bey: Bırakınız efendim... Mahdum bey de emsali gibi hevesini alsın!

Hayrettin Efendi: Bizim mahdum da; emsali de heveslerini alıncaya kadar hem Osmanlı lisan ve edebiyatı harap olacak, hem de benim şekerlerle Romanya unları..

Şadan Bey: Sizin şekerlerle Romanya unları, yahut tenekesini kırk bir buçuğa aldığınız Halep yağı hakkında bir diyeceğim yoktur. Fakat emin olunuz ki lisan ve edebiyatımıza hiçbir şey olmaz. Süleyman Nazif vaktiyle yazdığı bir makalede:

«Cenap Şahabeddin’in yed-i hâkimiyetindeki kilk-i galip kolay kolay ıskat edilemez.»

demişti. Ne kadar doğrudur. Siz emin olunuz efendipeder. Bunun da modası geçer... Zaman; bu devr-i edebîde küme küme şairleri, nasirleri ile sınıf-ı esâtire nakleder. (Elinde Hanımlar Âlemi gazetesi olduğu halde Mehmet Bey önde, aşçıbaşı arkada ve onun arkasında da Mesut olduğu halde içeriye girerler.)

\section{Dördüncü Meclis}

Evvelkiler - Mehmet Bey, Aşçı, Mesut

Hayrettin Efendi: «Mehmet Bey’e» O nedir elindeki kâğıt?

Mesut: Hanımlarısının Âlemisinin gazetesi...

Hayrettin Efendi: Nasıl, nasll? Aman bir daha söyle!

Mesut: «Anlatmaya çalışarak» Küçük Beyisinin elindeki ceridesini sormuyor musunuz? 
Hayrettin Efendi: Onu soruyorum.

Mesut: «Ciddiyetle» İşte efendim söyledim ya! Hanımlarısının Âlemisinin gazetesi... (Hayrettin Efendi'yle Şadan Bey kahkahalarla gülerler)

Mehmet Bey: Efendim... Siz yeni edebiyatı istihfâf ediyorsunuz ama bakını aşçıbaşının şiirlerini Hanımlar Âlemi gazetesi bile maa'l-takdir neşretti.

Hayrettin Efendi: «Ciddiyetle» Hanımlar Âlemi gazetesi aşçıbaşının şiirini mi koymuş?

Mehmet Bey: Evet efendim... (Hanımlar Âlemi’ni aşçıaşıya uzatarak) Müsaade buyurunuz da efendim kendi şiirini yine kendisi okusun!

Hayrettin Efendi: «Şaşırarak» Aşçıbaşı şimdi burada şiir mi okuyacak?

Aşçıbaşı: «Sırıtarak» Evet efendim... Müsaade ederseniz okuyacağım..

Hayrettin Efendi: (Yine hayretle) Bu gazetede mi?

Mehmet Bey: Evet efendim...

Mesut: Hanımlarısının Âlemisinin gazetesi işte...

Hayrettin Efendi: (Hiddetle) Sen sus? (Mehmet Bey’e) Hanımlar Âlemi gazetesi aşçıaşının şiirini nereden bulmuş.

Mehmet Bey: Gönderdik babacı̆̆ım... Onlar da maa'l-takdir dercettiler.

Hayrettin Efendi: (Aşçıbaşıya) Ver bakayım şu gazeteyi...

Aşçıbaşı: Buyurun efendim (Gazeteyi efendiye verir)

Hayrettin Efendi: (Bakarak) Evet yazmışlar...

Mehmet Bey: Elbet dercedilir efendim... Bu gibi asar-ı nefisenin heba olup gitmesine kimin vicdanı razı olur? Rica ederim efendim, veriniz aşçıbaşıya da kendi şive-i mahsusuyla okusun.

Hayrettin Efendi: (Yine gazeteyi okuyarak) Ay. Aşçıbaşının imzası da var.

Aşçıbaşı: (Sırıtarak) İmzam da var efendim.

Hayrettin Efendi: (Aşçıya) Senin ismin Ahmet değil mi?

Aşçıbaşı: Ahmet’tir efendim... Hemşehriler arasında bana Güdük Ahmet derler.

Hayrettin Efendi: Ya orada imzanın yanında bir çınar lakırtısı da var

Aşçıbaşı: Biz memlekette Çınaroğulları diye anılırız da...

Hayrettin Efendi: (Gazeteyi vererek) Anladım, anladım.. 
Mehmet Bey: Gördünüz ya efendim.. Hem de üzerine eş’âr-ı güzideden demişler...

Mesut: Aşçıbaşının edebiyatını gazeteciler beğenmişler öyle mi?

Mehmet Bey: (Mesut’a) Elbet beğenirler... Asar-ı nefiseyi erbabı pek çabuk takdir eder.

Hayrettin Efendi: (Şadan Bey'e) Dikkat buyurulur mu? Aşçıbaşının yaveleri de asar-ı nefise meyanına idhal olunuyor. Aman Yarabbi.

Şadan Bey: Müsaade buyurunuz da okusun. Anlayalım.

Hayrettin Efendi: (Aşçıya) Oku bakalım.

Mehmet Bey: (Aşçıya) Aşçıbaşı. Dikkatli oku. Şiveni hiç bozma.

Aşçıbaşı: (Mehmet Bey’e) Merak etme beyim.

Hayrettin Efendi: Haydi, haydi... Dinliyoruz.

Aşçıbaşı: (Kendine çeki düzen verdikten ve bir iki kere öksürdükten sonra okumaya başlar:)

Acı yalağın acıdır suyu

Küçük beyimin tatlıdır huyu

Şişli'den ötedir Zincirlikuyu

Yandı tutuştu gönül ocağı

Hayrettin Efendi: (Hiddetle) Olmaz efendim olmaz... Bu ne kepazelik... Kuyu ile huyunun takfiyesi caiz midir?

Mehmet Bey: Efendibabacığım. Bu serbest vezindir, serbest vezin...

Hayrettin Efendi: (Yine hiddetle) Serbest vezin, serbest kafiye ne demek oluyor. Bundan bilmem ne kadar zaman evvel merhum Recaizade de «Kafiye sem` içindir» demişti de dünyayı adamcağızın başına geçirmişler:

Kafiye sem` içindir bırakın kaideyi

Böyle talim ediyor vay gidi üstad-ı edep!

diye sarakaya almışlardı.

Mehmet Bey: O zaman öyle demişler... Fakat şimdi lisan ve edebiyatımızın tekâmülüne çalışıldı̆̆ı bir sira...

Hayrettin Efendi: Beni günaha, belaya uğratmayın. Lisan böyle maskaralıklarla mı tekâmül eder.

Şadan Bey: «Hayrettin Efendi'ye» Efendim. Beyhude yere hiddet buyurmayın. Müsaade ediniz de ikmal etsin. 
Hayrettin Efendi: Ama efendim insanı zorla kızdırıyorlar. Hem maskaralık, hem de lisan ve edebiyat tekâmül ediyormuş...

Şadan Bey: «Aşçıya» Devam et aşçıbaşı.

Aşçıbaşı: Devam ederek:

Mercimek, nohut, bulgur çorbası

Kilerde asılı pirinç torbası

Delindi bugün sakanın kırbası

Yandı tutuştu gönül ocağı

Hayrettin Efendi: «Haykırarak» Olmaz... Vallahi olmaz efendim... Bu ne maskaralık, bu ne rezalet... Sakanın kırbasına pirinç torbası kafiye olur mu? Hem efendim bulgur çorbasıyla nohudun şiirde ne yeri var?

Mehmet Bey: Lakin efendibaba siz bilmiyorsunuz ki...

Hayrettin Efendi: «Sözünü keserek» Neyi bilmiyor muşum... Bu maskaralıkları bilmekten bilmemesi hayırlı...

Mehmet Bey: «Aşçıya» Sen devam et aşçıbaşı.

Aşçıbaşı: Peki efendim. «Devam eder:»

Fasulye, kabak, yediği halta bak

Hayrettin Efendi: «Haykırarak» Artık tahammül edemem... Şiire böyle müstehcenat, böyle müstekreh şeyler girer mi?

Aşçıbaşı: «Devam ederek:»

Fasulye, kabak, yediği halta bak

On beşe pilav bir küçük tabak

Güllaç var ama pahalı kaymak

Yandı tutuştu gönül ocağı

Hayrettin Efendi: «Hiddetle» Gördünüz mü rezaleti?

Şadan Bey:Hiddetlenmeyin efendim... Ne denir?

Aşçıbaşı:«Devam ederek»

Tulumba tatlısı, sigara böreği

Bu sene bulunmaz Paskalya çöreği

Yirmiye diyorlar bir kuzu yüreği

Yandı tutuştu gönül ocağı 
Hayrettin Efendi: Aman yarabbi. Aklıma fenalık gelecek... Şimdi zıvanadan çıkacağım. Böyle şiir olur $\mathrm{mu}$ ?

Mehmet Bey: Ah efendibabacığım. Takdir etmiyorsunuz... Gücenmeyiniz.

Hayrettin Efendi: «Haykırarak» Bu hezeyanların neresini takdir edeyim?

Aşçıbaşı: «Okumakta devam eder:»

Ne kadar güzel Memiş’in kızı

Hayrettin Efendi: «Hızlıca» Dur. Bu mısrada hece vezni değil aruz vezni var. «Şadan Bey’e» Dikkat buyurunuz. «Aşçıya» O mısrayı bir daha oku.

Aşçıbaşı: «Sirıtarak» Baş üstüne efendim. Galiba çok beğendiniz?

Hayrettin Efendi: Haydi sen şimdi oku da...

Aşçıbaşı: «Okuyarak:»

Ne kadar güzel Memiş'in kızı

Hayrettin Efendi: «Şadan Bey’e» Ben bilmez miyim hiç? Ahenginden anlarım. Ne raksan vezindir, nerede olsa kendini gösterir. Mütefâilün, mütefâilün vezninde... İşte takdimi de:

Ne kadar güzel, mütefâilün

Memiş’in kızı, mütefâilün

Şadan Bey: Evet efendim, hakkıâlîniz var. Mütefâilün vezninde...

Hayrettin Efendi: Bilmez miyim efendim, bilmez miyim hiç? Hatta merhum Mehmet Celal'in bu vezinde hatırımda kalan bir şiiri vardır. Dur bakayım ne idi o? Hah hatırıma geldi. Şöyle başlar:

Yine başladı şeb-i nevbahar

Esiyor nesim-i ferahfeza

Geliyor terâne-i cûybâr

Ötüyor hezar-gam aşina

Uçuyor uzakta sehâbeler

Uyuyor deniz, doğuyor kamer

Şadan Bey: Ne güzel, ne raksan bir vezin... Kuzum pederefendi hazretleri bir bahar gecesini tasvir eden bu güzel manzumenin alt tarafı da hatırınızda mı?

Hayrettin Efendi: Hatırımda idi ama... «Bir tutam enfiye çekip aksırdıktan sonra» Şu parçası da hatırıma geldi. Ne güzeldir:

Gecenin revâhı münteşir

Bakarım semâyı mükevkebe

Görüyorum hayâlini müstetir 
Dalarım semâ-yı müzehhebe

O uyur semâda sükûn ile

Sen uyu sadâ-yı gusûn ile

Mehmet Bey: Efendibabacığım? Müsaade buyurunuz da aşçıbaşı şiirini ikmal etsin?

Hayrettin Efendi: «Aşçıya» Oku bakalım şairbaşı?

Aşçı: «Sırıtarak» Efendim; benim şiirin de veznesini beğendiniz galiba?

Hayrettin Efendi: Veznesi değil, vezni, vezni...

Mesut: Efendi! Veznesinden başka vakfiyesi de olacak değil mi?

Hayrettin Efendi: «Haykırarak» Sus be budala, beceremediğin sözü ne söyleyip durursun? Hâlâ vezne, vakfiye deyip duruyor.

Aşçı: Müsaadenizle okuyorum efendim,

Hayrettin Efendi: Haydi, oku,

Aşç1:

Ne kadar güzel Memiş’in kızı

Hele gözleri seher yıldızı

Kalbimin üstünde bir derin sızı

Yandı tutuştu gönül ocağı

Mehmet Bey: Efendibaba, beğeniyorsunuz ya?

Hayrettin Efendi: «Aşçıya» Haydi, haydi, oku da bitir;

Aşçı: Emriniz başımın üstüne efendim, okuyum «Okur»

Hey aşçıbaşı! Sen susma öyle!

Puf böreğine bir şiir söyle?

Şair olanlar durur mu böyle?

Yandı tutuştu gönül ocağı

Mehmet Bey: Nasıl efendibabacığım nasıl? Efkârdaki, hissiyattaki terakkiyi, rikkati, nezaketi gördünüz mü? Bakınız, gençler nasıl bir inkılap-ı edebî yapıyorlarmış anlayınız,

Hayrettin Efendi: «Hiddetle» Haydi oradan... Beni günaha, belaya uğratma,

Mehmet Bey: İşinize gelmeyince böyle söylüyorsunuz; fakat ne deseniz, ne kadar hiddetlenseniz beyhudedir, bu cereyan-ı edebiyyenin önüne geçilemez, o, önüne gelen her haili yıkacak, Naci, Fikret devirlerini bir remad-ı nisyan altında bırakacaktır, «aşçıya» haydi aşçıbaşı biz gidelim.

Aşçı: Gidelim efendim «Mehmet Bey’le aşçı odadan çıkarlar»

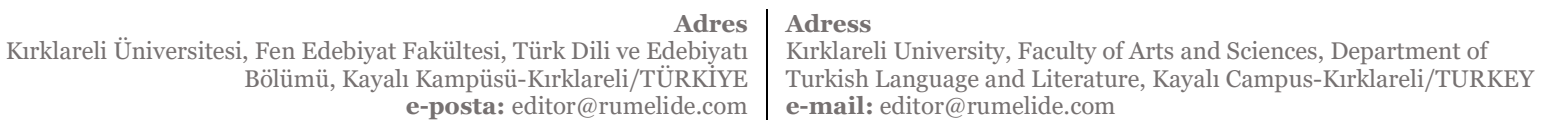


Mesut: «Kendi kendine» Onlar gittiler, ben de arkalarından gideyim de bakalım yine nasıl yapıyorlar vezneli, vakfiyeli, parmaklıklı edebiyatını göreyim, «Gider»

Hayrettin Efendi: Gördünüz mü maskaralığın derecesini? İki kaval, bir çoban pınar başı, ayran derken puf böreği de şiirin mülhem ve müvellidi olmaya başladı, bunu da ekşili yahni ile kebap köftenin, telkadayıf ile fındıklı güllacın takip edeceğine şüphe etmeyiniz! (İcini çekerek) Ah! Rahmet olsun canına! Şimdi Muallim Naci olmalı idi de...

Şadan Bey: Haberiniz yok mu efendim?

\section{Hayrettin Efendi: Neden?}

Şadan Bey: Bugünün Muallim Naci'sinden....

Hayrettin Efendi: (Hayretle) Bugünün Muallim Naci’si kim oluyor?

Şadan Bey: (Cebinden Hanımlar Âlemi gazetesi çlkarıp uzatarak) Bu gazeteyi okumuyor musunuz?

Hayrettin Efendi: O nedir evladım?

Şadan Bey: Hanımlar Âlemi gazetesi

Hayrettin Efendi: Aşçının maskaralığını koyan gazete değil mi? Bırak Allah aşkına!

Şadan Bey: Siz aşçının şiirini dercettiğine bakmayınız! Onun sahibinin ne alaycı bir herif olduğunu bilmezsiniz!

Hayrettin Efendi: Alaycı mı?

Şadan Bey: O kadar alaycı ki haddinden fazla... Önüne geleni sarakaya alır. Aşçının şiirini de mahzâ alay için koymuştur. Hâlbuki siz gazetenin sair münderecatını okusanız...

Hayrettin Efendi: Kimler yazıyor?

Şadan Bey: Kadın, erkek birçok kimseler yazıyor. Fakat iki üç haftadır Muhyittin imzasıyla makaleler yazılıyor ki galiba bu adam Muallim Naci'ye haydi haydi rahmet okutacak...

Hayrettin Efendi: (Gülerek) Deme Allah'ı seversen...

Şadan Bey: Efendim bir kere makaleleri okuyunuz da görürsünüz! Hem bu adam edebiyat-ı garbiyyeye de aşina...

Hayrettin Efendi: Bu Muhyittin Bey acaba kimdir?

Şadan Bey: Bu, bildiğiniz Muhyittinlerden değil... Hem buna Muhyittin Efendi diyorlar

Hayrettin Efendi: Muhyittin Efendi mi?

Şadan Bey: Evet efendim... Muallim Muhyittin Efendi 
Hayrettin Efendi: Muallim Muhyittin mi?

Şadan Bey: Öyle diyorlar...

Hayrettin Efendi: (Enfiyesini çekerek) Vallahi hoşuma gitti... Muallim Naci Efendi gibi bir şey...

Şadan Bey: Arz ettim ya efendim... Bugünün Muallim Naci'si...

Hayrettin Efendi: (Gazeteye göz gezdirerek) Zevk unvanlı bir makalesi var. Ay... Nigâhından Senin serlevhalı bir gazeli de var. Makaleyi sonra okurum. Bakayım şu gazel nasıl şey...

Şadan Bey: Lütfen okuyunuz da bendeniz de işiteyim

Hayrettin Efendi: (Şiiri okumaya başlar:)

Senin Nigâhından

Devlet umsa çok mu efserler nigâhından senin

Devlet-i aşk aldı tâb u fer nigâhından senin

Feyz alıp tenşit eder her dem sehab-ı ömrümü

Gamze-yi necm-i ümidim her nigâhından senin

Muktebis bir hande-i gülgûn 'izârından şafak

Bir mütercem neş'e ahterler nigâhından senin

Râh-1 aşk-ı zülfüne bir istiareymiş sırat

Bir kinâye sûriş-i mahşer nigâhından senin

Bir terennüm nev-bahâr âhengi hüsnünden doğan

Bir tebessüm âsumân yekser nigâhından senin

Çeşmine ma'tûf olunca doymaz istignâlara

Sanki hissiyât alır şeh-per nigâhından senin

Çok mu şi’rim olsa çeşmânın gibi 'ulvî-i me'âl

Mülhem oldu şimdi vahy-âver nigâhından senin

Şadan Bey: Beğendiniz mi efendim?

Hayrettin Efendi: Vallahi parlak... Hem de ben bu Muhyittin’i tanıdım.

Şadan Bey: Doğru söylemek lazım gelirse çok güzel yazıyor.

Hayrettin Efendi: Yazar efendim bilirim. Daha o zamanlar siz çocuktunuz! Merhum İsmail Safa ile bir kafiye meselesine girmişti, merhum yazdı, bu yazdı. Nihayet galebe bunda kaldı.

Şadan Bey: Ya... Bilmiyordum.

Hayrettin Efendi: Çoktan beri yazmıyordu. Matbuat âleminden çekilmişti. Demek başladı. Âlâ... Artık nev-hevesân-1 tahrir bundan sonra biraz düşünerek yazarlar. Zira bu adam en hurda nevakıs-ı edebiyyeyi de görür ve tenkit eder. Hem tenkit etmelidir de... Nedir o şiir diye ortaya çıkarılan alaca bulaca koşma kılıklı şeyler... Nedir o nesir namına meydana atılan küme küme masallar... Üç dört kişi 
çıkmış... Başına toplamış sekiz on çocuk.. Ayrı ayrı her birine sen edipsin, şairsin, dâhisin, üstatsın, lisan ve edebiyatımızın rükn-ü rasînisin! diyerek şımartmış.. Artık lafz-ı zekâ ve deha her hafta bunlardan birinin ser-i ibtihâc-ı makalatında.... İşte en garibi erbab-ı kalemden, hakikaten üstat olanlardan birinin meydana atılıp da «Yahu ne yapıyorsunuz? Âlem-i edebiyat dört buçuk çocuğun cevelangâh-ı gafilânesi olamaz» dememesi, demek için kendisinde bir cesaret bulamamasıdır. Lisan ve edebiyatımız üryan bir hâlde bırakılıyor da kimse aldırmıyor. Olmaz efendim, vallahi olamaz. Mektep açar gibi, dükkân açar gibi birdenbire lisan ve edebiyat tesis edilmez. Düşününüz! Milletin kâffe-i hakâyık-ı hissiyesine asırlardan beri vasıta-i tebliğ olmuş bir lisan ve edebiyat birdenbire nasıl değiştirilir? (Enfiyesini çekip aksırdıktan sonra) Her ne ise pek hoşuma gitti şu adamın tenkidata başlaması...

Şadan Bey: (Ayağa kalkarak) Efendim! Müsaade-i âlîyenizle...

Hayrettin Efendi: Pek az olmadı mı evladım? Görüşüyorduk.

Şadan Bey: İnşallah yine gelir, istifade, istifâza ederim efendim!

Hayrettin Efendi: (Ayağa kalkarak Şadan Bey’i kapıya kadar teşyi eder.) Teşrifinizden cidden memnun oldum. Bende-hâne her zaman sizindir. Sık sık teşrif buyurunuz da dertleşelim!

Şadan Bey: İnşallah efendim (çıkar)

Hayrettin Efendi: Zeki, fatîn bir gençtir. Terbiyelidir de... (Bir dakika düşündükten sonra) Canım yine bir tatlı istiyor. Düşünüyorum, haydi bir lalanga yaptırayım. Fakat aşçı unu da, şekeri de berbat edecek (Ellerini vurur, iki dakika sonra Hanife girer.)

\section{Beşinci Meclis}

Hayrettin Efendi, Hanife

Hanife: Bir emriniz mi efendim?

Hayrettin Efendi: Git hanıma söyle! Lalanga için un, yağ, pirinç hazırlasın!

Hanife: Peki efendim (Çıkar)

[Hayrettin Efendi:] Ben de gideyim, mutfaktan Arap ile oğlanı çekeyim. Lalangayı yaparken aşçıyı şaşırtmasınlar; bizim Halep hadîdi ile un, şeker vezneli, vakfiyeli şiir uğruna ziyan olmasın; (Odadan çlkar)

Perde iner.

Hitam 


\section{Kaynakça}

And, M. (1971). Meşrutiyet Döneminde Türk Tiyatrosu (1908-1923), Ankara: Türkiye İş Bankası Kültür. Çapanoğlu, M. S. (1961). 8 o Ylllkk Gazetecimiz Asaf Konselitçi, İstanbul: Sinan Matbaası.

Çetin, N. (2006). "Servet-i Fünûn Topluluğu Döneminde Edebiyat Nazariyatı ve Tenkidi”, Türk Dünyası Edebiyat Tarihi, Cilt 7, Ankara: Ankara Kültür Merkezi Başkanlığı, s. 590-610.

Dayanç, M. (2012). "Millî Edebiyat Dönemi, Milliyetçi Edebiyat ve Millî Edebiyat Kavramı Üzerine Düşünceler”, Eskişehir Osmangazi Üniversitesi Sosyal Bilimler Dergisi, S. 13/1, s. 91-103.

Ercilasun, B. (1997). "Edebiyatta Millîlik ve Milliyetçilik”, Yeni Türk Edebiyat Üzerine İncelemeler 1, Ankara: Akçă̆.

Işık, İ. (2007). "Borsacı, Mehmet Asaf”, Türkiye Edebiyatçllar ve Kültür Adamları Ansiklopedisi, C. 2, s.731.

İnuğur, M. N. (1993). “Türk Basınına Yıllarca Emek Veren, Mehmet Asaf Borsacı”, Marmara İletişim Dergisi, S. 2, s. 161-168.

Mehmet Asaf [Borsacı] (1334/1918). Beyimin Edebiyata Merakı, İstanbul: Necm-i İstikbâl Matbaası (Matbaa-i Orhaniye).

Nutku, Ö. (1998). Dram Sanatı Tiyatroya Giriş, İstanbul: Kabalcı.

Özalp, N. A. (200o). “Müebbet Bir Tartışma: Edebiyatta Millilik”, Kaşgar (Edebiyat-Kültür), S. 16, s. 25-37.

Parlatır, İ. - Çetin, N. (1999). Genç Kalemler Dergisi. Ankara : TDK.

Seyfettin Özege Koleksiyonu, "Mehmed Asaf Borsacı", [Erişim tarihi: 07.12.2019]. https://bilgimerkezi.atauni.edu.tr/yordambt/yordam.php?aKutuphane=A\&aBolum=01

Ünaydın, R.E. (2000). Diyorlar ki, (hzl. Şemseddin Kutlu), Ankara: Kültür Bakanlığı.

Tarakçı, C. (1994). Muallim Nâcî Efendi ve Eserlerinden Seçmeler, Ankara: Kültür Bakanlığı.

Töre, E. (2008). “II. Meşrutiyet Dönemi Türk Tiyatrosu”, Doğu Batı, 11/45, s. 215-251.

Yalçın, A. (2002). II. Meşrutiyette Tiyatro Edebiyatı Tarihi, Ankara: Akçağ.

Yetiş, K. (1999). “Millî Edebiyat Anlayışı”, İlmî Araştırmalar Dil ve Edebiyat İncelemeleri, S. 8, s. 267284. 